\title{
ENPLEGUKO BORONDATEZKO GIZARTE AURREIKUSPENEKO ERAKUNDEEK (BGAE) ETA ENPLEGUKO PENTSIO-FUNTSEK KAPITAL ARRISKUAN EGITEN DUTEN INBERTSIOA
}

\author{
Rosa M.a Ahumada Carazo \\ Unibertsitateko Irakasle Titularra (UPV/EHU) \\ Ainhoa Goienetxea Murgiondo \\ Enpresen Administrazio eta Zuzendaritza Gradua eta Enpresa Zuzendaritza Berrikuntza \\ eta Nazioartekotzearen ikuspegik Masterra
}

DOI: $10.1387 /$ lan-harremanak.16576

\section{ABSTRACT}

Lan honetan Enpleguko Borondatezko Gizarte Aurreikuspeneko Erakundeek (BGAE) eta Enpleguko Pentsio-Funtsek Kapital Arriskuan egiten dituzten inbertsioak ikertzen dira. Horretarako, lehendabizi Kapital Arriskuaren ezaugarriak deskribatzen dira, jarraian erakunde hauek inbertitzeko orduan dituzten eskaeretan sakontzeko. Lan honetatik hainbat ondorio atera dira, eta hauek Borondatezko Gizarte Aurreikuspeneko Erakunde eta Espainiako Pentsio-Funtsen Gestoretako Inbertsio Zuzendariei eginiko inkestetan oinarrituz burututako analisi kualitatibo baten bitartez kontrastatzen dira.

Hitz gakoak: Kapital Arriskua, Enpleguko Pentsio-Funtsak, Enpleguko Borondatezko Gizarte Aurreikuspeneko Erakundeak (BGAE).

Este trabajo analiza la inversión en Capital Riesgo de los Fondos de Pensiones y las Entidades de Previsión Social de la modalidad de empleo. Para ello, en primer 
lugar se describen las características del Capital Riesgo como inversión para seguidamente indagar sobre las demandas de estas instituciones a la hora de invertir. Esto nos lleva a una serie de conclusiones que son contrastadas a través de un análisis de tipo cualitativo, basado en encuestas a los Directores de Inversiones de las principales Gestoras de Fondos de Pensiones en España y de Entidades de Previsión Social del Pais Vasco de la modalidad de empleo.

Palabras clave: Capital Riesgo, Fondos de Pensiones, Entidades de Previsión Social Voluntarias.

This paper analyzes the investment in Venture Capital that Employment Pension Funds and Employment Voluntary Provident Societies, known as EPSV, the characteristics of Venture Capital as an investment are described, to afterwards inquire about the claims of these institutions when investing. This leads to a number of conclusions that are contrasted through a qualitative analysis based on surveys of Investment Directors from Pension Funds in Spain and Voluntary Provident Societies in the Basque Country.

Keywords: Venture Capital, Private Equity, Employment Pension Funds, Employment Voluntary Provident Societies (EPSV) 


\section{Sarrera}

Borondatezko Gizarte Aurreikuspeneko Erakunde eta Pentsio-Funtsen BGAE eta PF aurrerantzean, inbertsioen barne aurkitzen den Kapital Arriskuaren analisiarekin hasteko, aipatutako babes sozialeko instrumentuak gizarte aurreikuspen osagarriaren testuinguruan kokatu behar dira.

Gure herrialdean, Espainiako Konstituzioa da babes sozialaren erreferentziazko markoa. Bertan ez da babes sozialaren ${ }^{1}$ kontzeptua azaltzen, bai ordea Gizarte Segurantza, Osasun-Laguntza eta Osasunarena. Hain zuzen ere, III. Kapituluan «Politika Sozial eta Ekonomikoaren gida oinarriez», 41. artikuluak ondorengoa dio": "Botere publikoek hiritargo guztiarentzat giza asegurantza delakoaren erregimen publiko bat mantenduko dute, beharrizan egoeretan laguntza eta giza prestapenak garantizatuz eta batez ere enplegu ezaren garaian. Laguntza eta gehigarrizko prestamenak libreak izango dira» ${ }^{3}$. Hori dela eta, babes soziala hiru sistemetan antolatzen da, sistemaren hiru pilareak ${ }^{4}$ bezala ezagutzen direnak.

Lehenengo pilarean Gizarte Segurantza barneratzen da, hau da, pentsio publikoen sorrera. Bere baitan oinarrizko maila eta kontribuzio maila daude. Oinarrizko mailan prestazio ez kontributiboak, osasun laguntza, prestazio familiarrak eta gizarte zerbitzuak batzen dira. Hauek guztiak zergen bitartez finantzatzen dira. Kontribuzio maila, ordea, derrigorrezkoa da besteren konturako langile eta autonomoentzat. Langile eta enpresarien kotizazioen bitartez finantzatzen da, banaketa sistemaren ${ }^{5}$ baitan, eta solidaritate eta unibertsaltasun printzipioek agintzen dute.

${ }^{1}$ Gai honen inguruko jarrera, teoria eta kontzeptuei buruz kontsultatu Ahumada eta Ispizua (2015: 86-92).

2 https://www.boe.es/legislacion/documentos/ConstitucionEUSKERA.pdf.

3 Pentsio Sistemaren unibertsaltasun, nahikotasun eta iraunkortasuna ikerketa analisi gaia da. Errandonea (2015: 19-91).

${ }^{4}$ Europar Batasunean, herrialdearen arabera, hainbat babes sozial sistema ezberdin daude. Termino orokorretan, Libro Verde sobre los Sistemas Complementarios de Pensiones en el mercado único (1997) delakoan azaltzen den bezala, pentsioen sistema globala hiru mailatan berregituratu daiteke. Erabilgarri: http://ec.europa.eu/social/main.jsp?langId=es\&catId=89\&newsId=839\&furtherNews=yes

5 Pay as you go system bezala ezagutua. 
1. irudia

Babes soziala osatzen duten hiru pilareak
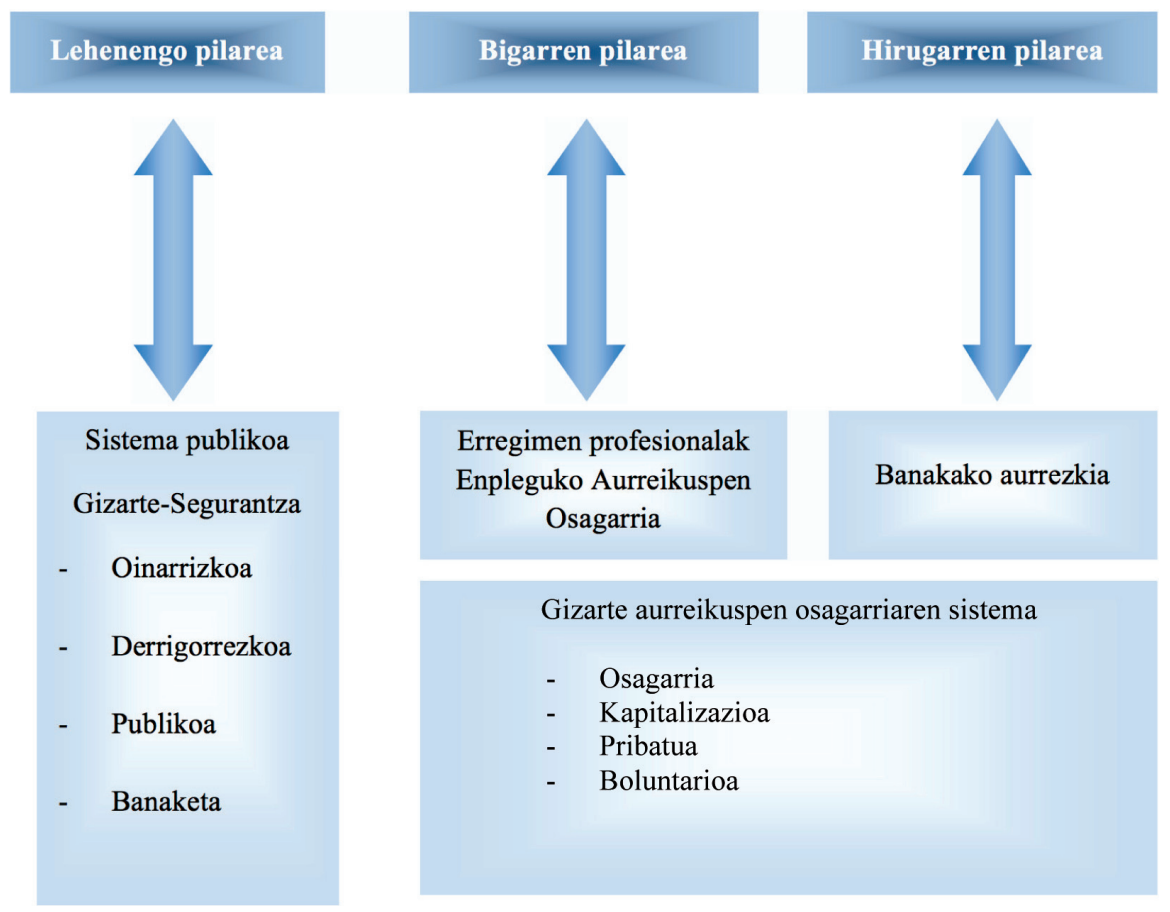

Iturria: Carazo eta Ispizua (2015:88).

Bigarren eta hirugarren pilareek gizarte aurreikuspen osagarria osatzen dute. Bigarren pilarean negoziazio kolektiboaren testuinguruan sortzen diren erregimen profesionalak batzen dira nagusiki, hau da, Pentsio Plan eta Funtsak, PPetaPF aurrerantzean, Mutualitate eta Aseguru Kolektiboak, bere baitan enpresetako BGAEak daudelarik. Sistema hauek enpresari eta enpresako langileei esker jartzen dira martxan. Pilare hau enpresariarentzat derrigorrezkoa da behin plana martxan jarri ondoren, langilearentzat boluntarioa da eta prestazioak ez dira Gizarte Segurantzaren prestazioen ordezkoak ${ }^{6}$.

Hirugarren mailak, bigarrenarekin batera, gizarte aurreikuspen osagarria osatzen du. Hirugarren pilare hau, ordea, banakako aurrezkian oinarritzen da, hau da, PPetaPF eta banakako aseguru eta mutualitateak batzen ditu, norbera-

\footnotetext{
${ }^{6}$ Europa mailan sistema hau derrigorrezkoa edo boluntarioa izan daiteke, lehenengo pilarearen ordezkoa edo osagarria eta gainera izaera pribatua nahiz publikoa izan dezake. Bigarren pilare hau kapitalizazio sistemen bitartez finantzatzen da (Alda et al., 2009:75).
} 
ren erabakitik sortutakoak. Pilare honek izaera pribatua eta boluntarioa dauka, eta malgutasuna dauka ekarpenei dagokienean. Nahiz eta banakako aurrezki formula bat izan, bere tratamendu fiskala ezberdina da mota honetako gainerako produktuekin alderatuz gero ${ }^{7}$.

ELGE (Ekonomia Lankidetza eta Garapenerako Erakundea) eta EBren ${ }^{8}$ gomendioei jarraiki, pentsio publikoen sistemak berregituraketa sakona jasan du azken urteetan zehar. Erreforma hauen helburua, bereziki gizartearen zaharkitzeak $^{9}$ dakartzan efektu finantzarioei egungo banaketa sistemarekin aurre egitea da, baita sistemaren iraunkortasuna bermatzea ere. Paraleloki, gizarte aurreikuspen osagarriaren bultzada proposatzen da.

Erreforma garrantzitsuenak 2011. eta 2013. urteetan barneratutakoak dira. $2011 \mathrm{n}^{10}$ erretirorako adina, kotizazio oinarriaren kalkulurako aldia eta pentsioaren kalkulurako kotizazio urteak igo ziren. "Jasangarritasun faktorea» ere aurkeztu zen. Azken hau 67 urteko bizi itxaropen media bat oinarritzat hartuta kalkulatzen den koefiziente bat da, erreferentziatzat adin horretako azken 5 urteetako bizi itxaropena kontutan izanik ${ }^{11}$. Indize honen arabera, bizi itxaropena handitzen den heinean, pentsioa geroz eta txikiagoa izango da. 2013. urtean «Pentsioen Errebalorizazio Indizea»" ${ }^{12}$ barneratu zen ${ }^{13}$, pentsioen urteroko igoera definitzen duena. Indize hau Gizarte Segurantzarekin loturiko hainbat sarrera eta gasturen orekaren emaitza da, eta «zoru» eta «sabaiak» ${ }^{14}$ dauzka. Horretaz gain, "Jasangarritasun Indizearen» ezartze data aldatu zen eta 2019 jarriko da abian.

Nahiz eta kotizazio oinarri eta pentsio maximo ${ }^{15}$ bat egon, Gizarte Segurantzaren pentsioek azken soldatarekin duten lotura oso handia da. ELGEn,

7 Hau da, kontu korronteen interesei, eperako gordailuei, dibidenduei etab. aplikagarriak dira.

8 EBak COM (2007) 603 amaiera, batu zuen Arrazoien Azalpena «Los sistemas de protección social de los distintos Estados miembros deben hacer frente al problema del envejecimiento demográfico. Las reformas adoptadas o previstas en la mayoría de los Estados miembros tienden a incrementar los regímenes complementarios de pensión, algo que numerosos Estados miembros fomentan activamente».

9 Espainiako Gizarte Segurantzaren ereduan demografiak izugarrizko garrantzia dauka. Adibidez, 1919. urtean, erretirorako adin arrunta 65 urte zirenean, bizi itxaropena 45 urtetakoa zen. 1967. urtean gaur egun daukagun sistema eratzean, bizi itxaropena 69 urtetakoa zen. Hortaz, bizi itxaropenak eta erretirorako adinak ez dira neurri berean garatu. Ondorioz, Espainia pentsio sistemaren populazioaren zaharkitze prozesu baten aurrean aurkitzen da, eta eraldaketak beharrezkoak suertatzen dira.

${ }^{10}$ Ley 27/2011, de 1 de agosto, sobre actualización, adecuación y modernización del sistema de Seguridad Social (BOE núm. 184, de 2 de agosto de 2011).

${ }_{11}$ Horretarako, Gizarte Segurantzaren heriotza-taulak hartuko dira kontuan.

12 IPR bezala ere ezagutua.

13 23/2013 legea, abenduaren 23koa, Jasangarritasun Faktorea eta Gizarte Segurantzaren Pentsio Sistemaren Errebalorizazio Indizea arautzen duena, BOE zbk. 309, abenduaren 26koa.

$14 \% 0,25$ eta KPI+\%0,50 artean aurkitzen da.

152016 an pentsio maximoa $2.567,28 € \mathrm{da}, 14$ ordainsarirekin, $35.941,92 €$ urtean. kotizazio oinarri maximoa $3.642 € 12$ hilabetean, hau da, $43.704 €$ urtean. 
soldata medioaren ordezkapen tasa ${ }^{16} \% 53 \mathrm{koa}$ da gizonezkoentzat eta $\% 52 \mathrm{koa}$ da emakumezkoentzat. Espainiaren kasuan, 2014an ordezkapen tasa medioa \%85,1 ekoa zen, autonomia erkidegoen artean ezberdintasunak nabarmenak izanik. Adibidez, Euskal Autonomia Erkidegoko tasa \%92,1ekoa da, Balearetan \%68,4koa delarik (Herce, 2015:15). Aztertutako ELGEko ${ }^{17} 34$ herrialdeen artean, ratio hau Mexikoko \%25 eta Herbeheretako \%90 artean aurkitzen da, lanean hasi berri direnen kasuan. Espainia \%80aren gainetik mantentzen da.

Hori dela eta, Espainian orain arte Gizarte Segurantzaren sistema publikoa nagusitu dela ondorioztatzen da, hau da, lehenengo pilarea. Hala ere, nagusiki gizartearen zaharkitzeari aurre egiteko martxan jartzen hari diren erreformen ondorioz, pilare hau ahultzen hasi da. Guzti honi egungo krisi egoerak, langabezia tasa altuak eta lan prekarietateak lagundu dio. Hori dela eta, gertuko beste herrialde batzuetan bezala, sistema publikotik jasotzen den pentsioa osatzeko aukera ezberdinak bilatzen dira. Horretarako, sistema osagarriak aukera bat dira, lan-harremanetan oinarritutakoak bereziki. Ondorengo ataletan esparru honetako bi aukera aztertuko dira: Enpleguko BGAE $^{18}$ eta Enpleguko PPetaPFak ${ }^{19}$, Kapital Arriskuaren analisiaren ostean.

\section{Kapital arriskua}

Kapital Arriskua (KA), epe ertain eta luzera enpresa ez finantzario, izaera higiezina eta etorkizunerako hazkunde potentziala dutenei baliabideak hornitzean

16 Ordezkapen tasa Gizarte Segurantzaren pentsioa edo pasiboko errenta eta azken soldata edo aktibo errentaren arteko zatiketa da.

17 ELGE (2015): Pensions at a Glance 2015 OECD and G20 Indicators, or. 23. http://www. oecd.org/publications/oecd-pensions-at-a-glance-19991363.htm (azken kontsulta data 2016/04/25).

18 Lan honetan ez dira BGAE preferenteak landuko.

19 Gainera, gizarte aurreikuspeneko instrumentu hauetan kudeaketaren ikuspegitik eraginkorragoak egin ahal dituzten aspektuak aurkezten dira. Ondarearen administrazioaren testuinguruan kokatuz gero, PPetaF eta GEBEen kudeaketak eredu ezberdinak jarraitzen ditu likidezia, aldizkako ekarpen/kontribuzio, parte-hartzaile/bazkideen eskubideen mobilizazioa, irteera eta sarrera fluxuen estimazioa, parte-hartzaile/bazkideen esku-hartzea, onuradunak etab.-ei dagokienean. Aldagai hauen datu zehatzak ikusteko: Ahumada, 2002. Horiek guztiak BGAE eta PPetaFen kudeaketa inbertsio funtsenaren oso antzekoa dela egiaztatzen du. Gainera, ondarearen kudeaketaren eraginkortasunari loturiko ebidentziak daude. Tradizionalki, enplegu sistemek lortutako emaitzak banakako sistemek lortutakoak baino altuagoak izan dira. Adibidez, azken 10 urteetan zehar enpleguko PFek errentagarritasun medio ponderatua \%3,23 lortu dute, eta banakakoek \%1,95. Inverco: http://www.inverco. es. BGAEen kasuan ez dago informazioa eskuragarri, nahiz eta Eusko Jaurlaritzak 2016. urtean argitaratzeko asmoa duen. Nazioartean, errealitatea ildo beretik doa. Adibidez, EEBBtan, Individual Retirement Accountek (IRA) \%2,2 errentagarritasuna eskuratu zuten, Enplegu Aportazio Definituko Planek \%3,1 eta Prestazio Definitukoek \%4,7, 2015eko datuen arabera 2000-2012 arteko datuak izanik (Munnell et al., 2015). 
oinarritzen den aktibitate ekonomikoa da. Inbertsio honen desinbertsio edo epe ertain luzera partizipazioen salmentarekin gainbalio bat lortzea nahi $\mathrm{da}^{20}$.

KA enpresentzat finantzazio aukera bat gehiago da, enpresa berrientzat ${ }^{21}$ edo hazkunde ${ }^{22}$ eta nazioartekotze ${ }^{23}$ proiektuak dituztenentzat batez ere. Aipatutako enpresek arrisku handiko proiektuak burutzen dituzte eta teknologia eta berrikuntzarekin erlazionatutako sektoreetan aritu ohi dira. Kasu hauetan ez da erraza izaten iturri finantzario tradizionaletatik, bankua esaterako, finantzazioa eskuratzea. Hori dela eta, enpresa hauek kapital merkatu tradizionalaren osagarriak diren beste formula batzuetara jotzen dute, KA adibidez (Goienetxea, 2015: 33-34).

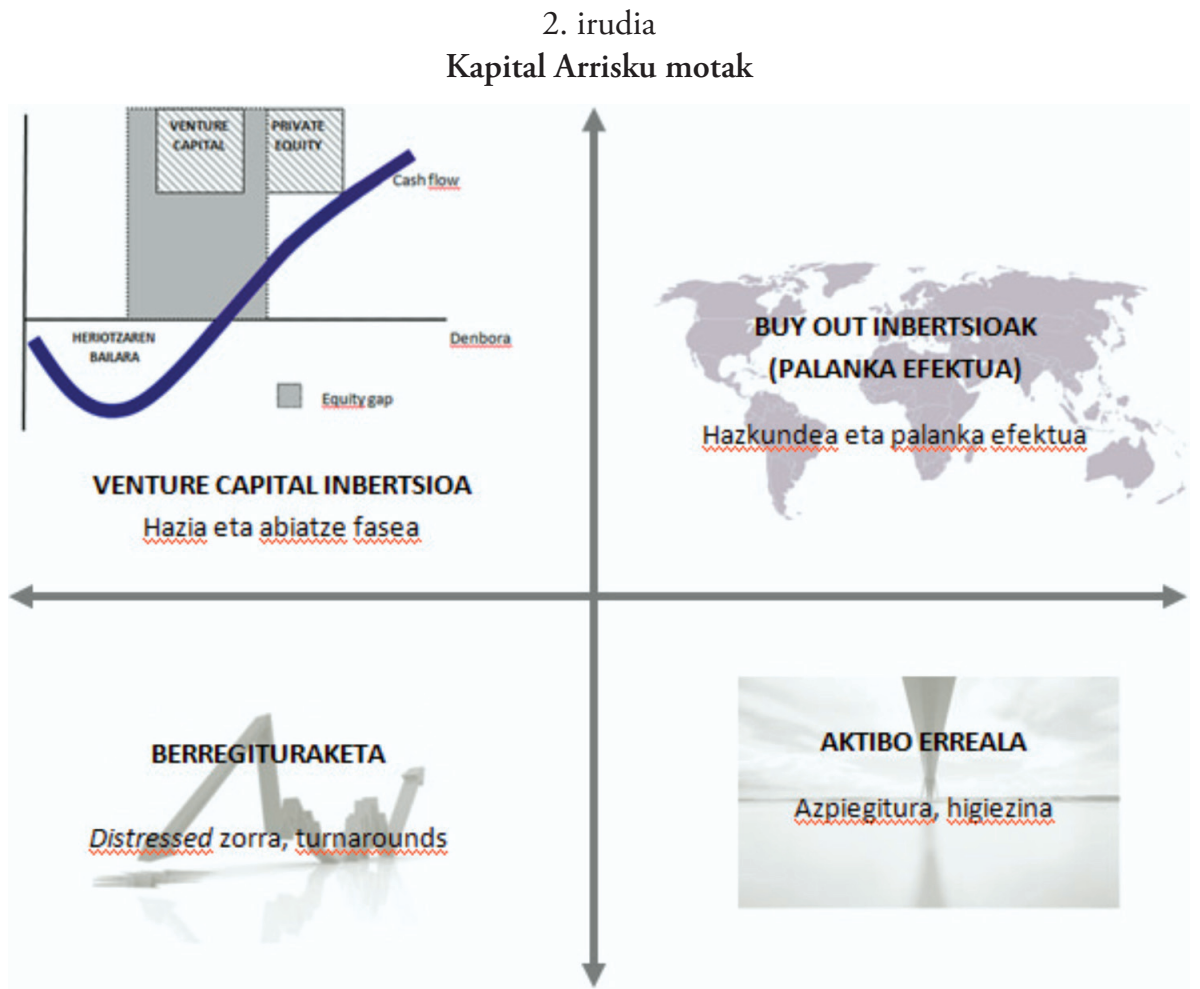

Iturria: norberak egina, Van Tichelen (2008) eta Goienetxea (2015) lanetan oinarrituta.

\footnotetext{
20 Informazio gehiago izateko, kontsultatu Hoyos eta Blanco, 2014.

21 Start-up deituak.

22 Zerbitzu eta produktu berriak eskaintzea, adibidez.

23 Start-up enpresa sortu berriak edo ibilbide gutxikoak dira.
} 
KAaren barnean mota ezberdinetako inbertsioak daude, enpresa aurkitzen den fasearen edo inbertitzen duen proiektuaren araberakoak ${ }^{24}$. Sailkapen hau ondorengo taulan erakusten da:

Venture Capital erako inbertsioak enpresa berrietan burutzen direnak dira, fase berrietan dauden enpresetan, "hazi» eta «abiapuntuan» daudenetan, hain zuzen ere. Inbertsio hauek eskaintzen duten itxarondako errentagarritasun erakargarria eta jasandako arriskuagatik ezagutzen dira. Buy-Out erako inbertsioak, ordea, fase aurreratuagoetan dauden enpresei zuzentzen dira, hazkunde fasean daudenei zehazki. Berregituraketa inbertsioak askotariko arrazoiengatik aldaketak jasaten ari den enpresari zuzentzen dira. Atal honetan Distressed zorra eta Turnaround zorra aurkitzen dira. Distressed zorra jaulkipenaren baldintza guztiak bete ezin dituzten enpresa edo herrialdeek jaulkitzen dute ${ }^{25}$. Turnarounds, bestalde, kaudimen gabezia edo bideragarritasun ekonomikoko plan bat duten enpresek jaulkitzen dute ${ }^{26}$.

Inbertitzaileen azken helburua inbertitzen duten enpresaren balioa handitzea da, horrela gainbalio bat lortzeko. Helburua betetzeko, inbertsioa burutzen den enpresei balio erantsia duten zerbitzuak eskaintzen zaizkie, hala nola, aholkularitza edo enpresaren kudeaketan laguntza, alderdi operatiboan hobekuntzak, apalankamendu ${ }^{27}$ efekturen erabilera handituz kapitalaren kostua txikitzeko eta enpresan balioa sortzeko (López eta Hurtado, 2008: 46-53).

KAn egindako inbertsioa bi motatako Kapital Arrisku Entitateren, aurrerantzean KAE, bitartez burutu daiteke. Alde batetik, kotizatzen ez duten enpresatan partizipazio tenporalak hartzea helburu dutenak, Kapital Arrisku Sozietateak (KAS). Beste alde batetik, inbertsioetako partizipazioengatik gainbalio eta ordainsarien truke, iraupen tenporal edo mugagabea duten funtsen kudeaketa garatzea eta eraketa bultzatzea helburu duten eta enpresa ez kotizatuetan inbertsioak egiten ospea duten espezialista esperientziadunak, Kapital Arrisku Entitateen Sozietate Kudeatzaileak, KAESK aurrerantzean (Alemany et al., 2011). Azken hauek Kapital Arrisku Funtsak (KAF) kudeatzen dituzte.

KAFak pertsona juridiko gabeak diren inbertitzaile ugariri dagokien banatutako ondareak dira. KAFen ondarea ezaugarri berak dituzten eta balore nominal gabeak ${ }^{28}$ diren partizipazioez osatua dago. Partizipazio horien jabeak $\mathrm{Li}$ -

24 Sailkapen orokor honen barnean desberdintasun nabarmenak daude Europa eta EEBBko ikuspegien artean. Xehetasun gehiagorako ikusi AAVV, 2005:27.

25 Mota honetako zorraren xehetasun gehiagorako, ikus Álvarez (2005).

26 Nahiz eta autore batzuek KAren barnean aktibo errealak, azpiegiturak eta higiezinen sektorea barneratzen duten, beste batzuek entitate propiodun aktibo bezala kontsideratu behar direla, KAtik kanpo, defendatzen dute.

27 Zordunketak errentagarritasun finantzarioan duen eraginari buruz, ikusi Gironella (2005).

28 CNMV: Autorización e inscripción de FCR. http://www.cnmv.es/Portal/Legislacion/ ModelosN/ModelosN.aspx?id=FCR\&idpf=4 (azken kontsulta data 2016/04/25). 
mited Partnerak dira, LP aurrerantzean. LPen konpromisoak General Partner (GP) gisa, jokatzen duen KAS batek kudeatzen ditu. KAFean eginiko inbertsio batean, LPak Limited Partnership Agreement, aurrerantzean LPA, sinatzen dute GParekin. GPen aholkulariek idatzitako dokumentu honek LPen eta GPen arteko erlazioa arautzen du. Alderdi bakoitzaren eskubide eta betebeharrak batzen ditu, baita funtsaren funtzionamendurako baldintzak ere (Van Tichelen, 2010: 26-30). Gainbalio bat irabaztearen helburua lortzeko, inbertitzaileek kapitala konprometitzen dute, eta 3-5 urte bitarteko epe batean kapital hori inbertitzen dute, GPak horrela eskatzen duenean. LPAn oinarrituta hartzen ditu GPak inbertsioei dagozkien erabakiak. Inbertsioen irteerak epe luzean burutzen dira ${ }^{29}$.

Operatibo ikuspegi batetik, hainbat dira KAren ezaugarriak finantza aktibo gisa, eta guztien artean ondorengoak nabarmentzen dira:

- Itxarondako errentagarritasuna epe luzean ${ }^{30}$, ez beti epe laburrean: errentagarritasuna inbertsioaren eta desinbertsioaren arrakastaren araberakoa da. Inbertsioaren epean, errentagarritasuna enpresaren aktiboen kudeaketaren hobekuntzekin, apalankamendu finantzarioaren bitartez dagokion kapitalaren kostua, eta enpresaren zuzendaritzan izango duen inplikazioarekin lotzen $\mathrm{da}^{31}$. Aipatu bezala, errentagarritasuna desinbertsio prozesuarekin erlazionatuta dago, adibidez, enpresa saldu edo likidatuz gero, enpresa burtsan kotizatzen hasten bada, funtsaren salmenta, etab.

— Errentagarritasunaren bolatilitatea beste aktibo batzuekiko: errenta finko eta aldakorreko aktiboen bolatilitatea ezberdina dela ondorioztatu daiteke aztertutako parametroetatik. Ondorioz, aktibo hauen eta KAren arteko korrelazioa txikia izan ohi da.

- Epe ertain eta luzerako inbertsioa: KAF batean egiten den inbertsioa ez da normalean likidoa izaten; LPak LPAn zehaztutakoaren arabera inbertsioak burutu behar dituzte, adostutako zenbateko eta epean, ohikoena 5 urte inguruko epea izanik. Penalizazio gabeko likidezia falta, hein handi batean KAren bigarren mailako merkatu handi eta garatu baten faltagatik da. LPak epe luzeko inbertsioak egitera konprometitzen dira, eta ez dute desinbertsiorako aukerarik izaten. Desinbertsio aukeren artean burtsan kotizatzea, hirugarren bati salmenta, likidazioa, berkapitalizazioa, eta bigarren mailako buy-out daude. Bigarren mailako merkatua

29 Espainiaren kasuan, inbertsio tipoa 5 urte gehi 1ekoa izan ohi da. Desinbertsioa bi eta zazpi urte arteren ondoren burutzen da, beti ere inbertsioaren epe globalaren mugarekin, $10+1+1$ dena.

30 Errentagarritasun hau loturiko aktiboa dagoen fasearen araberakoa izango da. Venture Capitalaren kasuan, hasierako unean kaxa-fluxu negatiboa izan dezake. Gain hartzen den arriskua nabarmena da start-up enpresetan inbertitzean, ibilbide laburra eta etorkizun ezezaguna dutelako.

31 Kasu batzuetan hau ez da horrela izaten, zuzendaritza talde osoaren edo zati baten kaleratzea dela eta. 
edo Seconddaries, aktibo mota hauen likidezia falta honi erantzun bezala planteatzen da. Merkatu honetan dauden inbertsioak salerosteaz gain, etorkizuneko konpromisoak ere salerosten dira. Merkatu hau geroz eta garatuagoa da, hazten ari da, eta salmenta egitura konplexuak ditu. Gainera, merkatuaren balorazioa sortzen laguntzen du, eta ondorengo funtsen bilketa errazten du. Horrela, KAko aktiboen likidezia arriskua jaisten da, KAn inbertitzea erakargarriagoa bihurtzen delarik, eta ondorioz, bigarren merkatu hau lehenengoaren motor bilakatzen da.

- Gardentasun mugatua: kasu batzuetan, agenteak inbertitzaileei eskaintzen zaien informazioa mugatzen du, hala nola posizioen informazioa, apalankamendua, arriskua edota estrategia. Datuen eskuragarritasun falta nabaria da, baita datu hauek erabiltzen dituzten lan akademiko sendoena ere. Zaila da behin betiko terminoetan funtsen jarduera eta inbertsio aktibitate maila irudikatzea ${ }^{32}$.

- Baloraziorako zailtasuna: inbertsioa eta erlazionatutako aktiboaren balioa merkatuan balioztatzea zaila da. Askotan $\mathrm{OTC}^{33}$ prezio baten beharra izaten da, edo balorazio sistema independente batena. Ondorioz, portfolioaren balorazioa subjektiboa izan ohi da.

Aztertzen de herrialdearen arabera, KAn eginiko inbertsioen garapena nabarmen aldatzen da. Espainia mailan, periodikoki KAren aktibitatearen inguruko txostenak argitaratzen dituen erakundea Asociación Española de Entidades de Capital Riesgo (ASCRI) ${ }^{34}$ da. 2015ean argitaratutako txostenaren arabera, 2014. urtean nazio mailako funts pribatuen bilketaren sendotzea garrantzitsua izan zen, eta funts berrien bilketaren normalizazioa gertatu zen, 2009an jasandako beherakadaz geroztik. 218 operadore aktibotatik, 98 nazioarteko entitateak dira, 103 nazio mailako entitate pribatuak eta 17 operadore nazional publikoak dira.

Likidezia handia sortu duten desinbertsio ugarik, bai Espainia eta nazioartean ere, azken bi urteetako funtsak sortzeko ingurua progresiboki hobetzea eragin dute. Txosten honen arabera, susperraldiaren azalpenerako faktore garrantzitsuenak ondorengoak dira Nazioarteko inbertitzaileen konfiantza handitzea espainiar ekonomian, eta FOND-ICO Global ${ }^{35}$ abian jartzea, izaera publikoa duen lehendabiziko funtsen funtsa, 1.200M€tako zuzkidurarekin 4 urteko inbertsio eperako.

32 Datu gehiagorako, kontsultatu Kaplan et al. (2015).

33 OTC, Over the Counter edo antolatu gabeko merkatua.

34 ASCRIren web orria ondorengoa da: http://www.ascri.org/ (azken kontsulta data 2016/04/25).

35 Datu gehiagorako, kontsultatu http://www.axispart.com/fondos-de-gestion/fond-ico-global/ que-es/ (azken kontsulta data 2016/04/02). 
2014. urtean baliabide hauen bitartez bideratutako aurrezkiak aldaketak jasan zituen. Lau urtez enpresen lehen fasetara zuzendutako inbertsioak gehiengoak izan ostean, 2014ean enpresa helduei eman zaie lehentasuna, zeinetan erosketa apalankatuak nagusi diren. Hala ere, Espainia mailan, lehen faseetan dauden entitateek jasotako finantzazioa $\% 26$ handitu zen.

Iturri beraren arabera, egungo egoera makroekonomiko eta mikroekonomikoa kontutan izanik, 2015 jarduerarako aurreikusitako datuak onak dira Venture Capital eta Middle Market sektoreentzat ASCRI (2016).

Analisia Europa mailara zabalduz gero, European Private Equity and Venture Capital Association ${ }^{36}$, EVCA aurrerantzean, da erreferentziazko iturria. Honen argitalpenen artean KAri buruzko urteroko txostena aurkitzen $\mathrm{da}^{37}$.

2015eko txostenaren arabera, 2014ko jarduera azpimarragarria izan da. Funtsen bilketak gorakada izan zuen, eta inbertsioak burbuila osteko mailara iritsi ziren, nahiz eta igoera hau egindako inbertsio zehatz batzuen ondorio izan. "Hazi» eta «abia» fasean aurkitzen direnak dira oraindik ere funts gehien jasotzen dituztenak.

Informe honen arabera, inbertitzaile instituzionalen \%40a baino gehiago Europatik kanpokoak dira. Funtsen hiruren bat baino gehiago Pentsio Funtsetatik jasotakoak dira, Funtsen Funtsetatik jasotakoak ondoren, eta atzetik gobernu agentziak eta aseguru konpainiak.

Errentagarritasunari dagokionez, ondorengo taulan KAaren errentagarritasuna neurtzen da, Europa eta Estatu Batuen artean dauden ezberdintasunak nabarmenak direlarik, amerikarrak garbi nagusitzen direlarik:

1.taula

KAren errentagarritasuna (\%) Europan 2014ko Abenduaren 31ean

\begin{tabular}{llllrr}
\hline & Urte 1 & 2 urte & 5 urte & 10 urte & 20 urte \\
\hline Venture Capital Totala & 7,93 & 15,26 & 11,53 & 6,74 & 5,46 \\
Buy-out Totala & 0,71 & 11,71 & 10,38 & 12,68 & 15,58 \\
Private Equity Totala & 1,32 & 11,76 & 10,28 & 12,12 & 14,35 \\
\hline
\end{tabular}

Iturria: BVCA Performance Measurement Survey 2013.

36 Informazio gehiagorako, kontsultatu http://www.investeurope.eu/

37 Asoziazio honetako eta Alemania, Israel, Japonia eta Erresuma Batuko asoziazioetako datuak dira herrialde hauetako KAFen finantzazioaren iturria eta inbertsio aktibitatearen analisiaren oinarria. Datu gehiagorako ikusi Mayer et al. (2005). 
2. taula

KAren errentagarritasuna (\%) EEBBtan 2014ko abenduaren 31 ean

\begin{tabular}{lccccc}
\hline & Urte 1 & 2 urte & 5 urte & 10 urte & 20 urte \\
\hline Venture Capital Totala & 21,49 & 18,04 & 16,07 & 10,28 & 35,44 \\
Buy-out Totala & 13,79 & 17,48 & 16,87 & 12,99 & 12,99 \\
Private Equity Totala & 14,53 & 17,09 & 16,25 & 12,12 & 15,79 \\
\hline
\end{tabular}

Iturria: BVCA Performance Measurement Survey 2013.

\section{Enpleguko borondatezko gizarte aurreikuspeneko entitateak}

1983. urtean arautu ziren lehen aldiz Euskadin BGAEak. Lehenengo Legea $^{38}$ orain dela urte batzuk argitaratu zen eta Araudia ${ }^{39}$ 2016an sartu da indarrean. BGAEen ikuskaritza Eusko Jaurlaritzari dagokio.

BGAEak Gizarte Segurantzan barneratu gabeko Mutualitateak dira, eta ondorioz, Gizarte Segurantzaren osagarria den gizarte aurreikuspenaren eremuan jarduten duten irabazi asmorik gabeko izaera pribatudun entitateak dira ${ }^{40}$. BGAEtan bazkide, sustatzaile, bazkide babesle eta zenbaki edo arruntak diren bazkideek hartzen dute parte ${ }^{41}$. Sustatzaileak entitatea sortzen duten pertsona fisiko edo juridikoak dira. Babesleak irabazi zuzenik gabe gobernu organoetan eta entitatearen garapen eta mantentze lanetan diharduten pertsona fisiko edo juridikoak dira. Bazkide zenbakidunak edo arruntak, ordea, prestazioak jasoko dituztenak dira. Heriotza kontingentzia gertatzen den kasuetan, bazkideek onuradunei aitortuko die prestazioa jasotzeko eskubidea. BGAEen gobernu organoak Batzar Orokorra eta Gobernu Batzordea ${ }^{42}$ dira, eta bertan bazkide eta onuradunek parte hartzen dute.

Gizarte Aurreikuspeneko Planak, GAP aurrerantzean, martxan jartzearekin egiaztatzen da Mutualitate hauen aktibitatea. Erretiroa, ezgaitasuna, heriotza, dependentzia, iraupen luzeko langabezia edo gaixotasun larriekin lotutako be-

38 5/2012 Legea, otsailaren 23koa, Borondatezko Gizarte Aurreikuspeneko Entitateena, EHAA zk. 47 martxoaren 6koa, aurrerantzean BGAEL. BOEn ere argitaratua zk. 65, martxoaren 16koa.

39 203/2015 Dekretua, urriaren 27koa, Borondatezko Gizarte Aurreikuspeneko Erakundeen otsailaren 23ko 5/2012 Legearen Erregelamendua onartzen duena, EHAA zk. 234, abenduren 9koa.

40 Arrazoien azalpena eta BGAEL 5. art.

41 BGAELko 15. art.

42 Bere osaera eta funtzionamenduari buruzko informazio gehiagorako ikus BGAELko 47 58 art. eta BGAE Araudiko 8-13 art. 
3. irudia

BGAE baten elementu pertsonalak

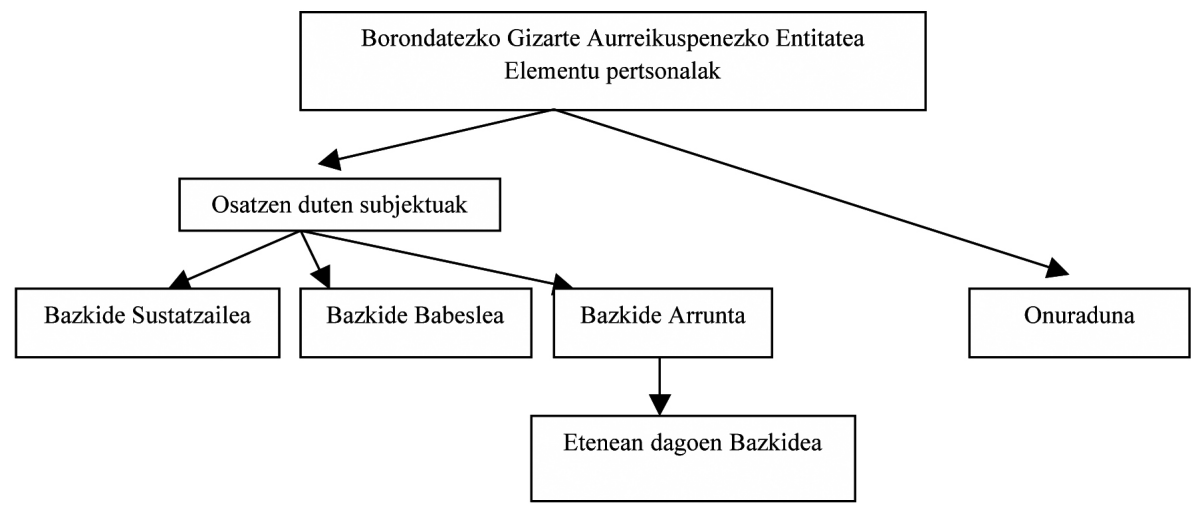

Iturria: Ahumada (2002: 55).

tebehar eta eskubideak arautzen dituzten akordioak ${ }^{43}$ dira GAPak. Ondorioz, GAPak honela definitu daitezke: Gizarte Segurantzari osagarriak diren erretiroa, ezgaitasuna, heriotza, dependentzia, iraupen luzeko langabezia edo gaixotasun larriak estaltzeko balio duten borondatezko akordio pribatuak. Prestazio hauek errenta, kapital edo forma mistokoak izan daitezke, kapitalizazio indibidualaren sistema finantzarioa aplikatuz.

Enpleguko GAPak enpresaren eremuan sortzen direnak dira, negoziazio kolektibo, enpresa akordio edo enplegu emailearen aldebakarreko erabakiaren ondorioz sortuak. Batez ere EAEn sustatu nahi den modalitatea da, Euskadiko Gizarte Aurreikuspen Osagarriaren Planean ${ }^{44}$ azaltzen den bezala. Fiskalitate ikuspuntutik ere enplegu motako sistema osagarrietara ${ }^{45}$ egiten diren ekarpenak laguntzen dira, dedukzio fiskal gehigarri ${ }^{46}$ baten bitartez, lurralde komunean kontutan hartzen ez den aspektua izanik. Mota hauetako Planetan bazkideen

43 Akordioa kontraktuala, asoziatiboa, konstituzio ekintza edo arautzailea izan daiteke. BGAELko 8. art. Akordio hau Planaren araudia da eta bazkide arrunta atxikitzen da, Atxikipen Aldizkariaren bitartez.

44 Eusko Jaurlaritzan 2006ko urtarrilaren 10ean onartua. Zehazki, objektibo bezala ondorengoa definitu zen: «Enplegu-sistemen bitartez, gizarte-aurreikuspen osagarria orokortzea. Gutxienez lanaren errentak jasotzen dituztenen edo profesionalen \%70era iristea da orokortzearen helburua; horrela, prestazio osagarri nahikoak eratuko dira». Eskuragarri: http://www.epsv.org/documentacion_ eu.php?tipo=12 (azken kontsulta data 2016/04/25)

45 Gizarte Aurreikuspeneko sistema osagarri guztiak barneratzen dira.

46 Parte hartzailearen ekarpenen dedukzio fiskalaren limitea $5000 €$ da, eta $8000 €$ sustatzailearen ekarpenen kasuan. Baterako limitea 12.000€ da. 
artean lan lotura edo antzekoa egoten $\mathrm{da}^{47}$ : bazkide sustatzailea enpresa da, eta langileak dira bazkide arruntak ${ }^{48}$.

Eusko Jaurlaritzak ${ }^{49}$ argitaratutako azken datuen arabera, 2014an Enpleguko 42 BGAE zeuden, 442.207 bazkiderekin. Guztien artean 12.183 milioitako ondarea osatzen zuten, horren ondorioz,eskubide ekonomiko medioa $27.550 €$ da. Ekarpen eta kuoten aldetik, jarduerak iraun zuen bitartean BGAE hauek 382 milioi euro baino gehiago jaso zuten, eta ia 500 milioi euro ordaindu ziren. Erreskateei dagokionean, 3 milioi baino zertxobait gehiago eskatu ziren. Duela gutxi, Gizarte Aurreikuspeneko Erakundeen Federazioak ${ }^{50}$ 2015eko irailari dagokion datuak argitaratu ditu. Iturri horren arabera, enpleguko 36 BGAEek 445.078 parte hartzaile zituzten, 11.436 milioi eurotako ondarea osatzen zutenak, horren kariaz batez besteko eskubide ekonomikoa $25.695 €$ da. Urte horretan 271 milioitako sarrerak izan ziren, eta prestazioak 356 milioitakoak izan ziren.

Ondarearen kudeaketari dagokionean, BGAE bakoitzak bere inbertsio politikaren printzipioen ${ }^{51}$ aldarrikapena egiten du, hiru urtez behin ikuskatuko dena $^{52}$, eta baita estrategia sozial, ingurumen, etika eta gobernu korporatiboaren $^{53}$ azalpena ere. Inbertsioak bazkide arrunten eta onuradunen interesen arabera burutu behar dira, beti ere araututako merkatuetan. Zehatzago adierazita, segurtasuna, errentagarritasuna, likidezia, dibertsifikazioa, sakabanatzea, kongruentzia monetarioa eta epeak euren helburuen araberakoak izango di$\mathrm{ra}^{54}$. BGAEen inbertsio posibleen artean errenta finkoa, merkatu arautuetako errenta aldakorra, aktibo egituratuak, akzioak, Inbertsio kolektiboko Instituzioen (IKI) partizipazioak/akzioak, ageriko gordailuak, ondasun higiezinak eta euren eskubideak, kreditu hipotekarioak, kreditu pignoratuak, KA, deribatuak,

47 Adibidez funtzionarioa, estatutarioa, langile bazkideena eta taldekideen artekoa sozietate kooperatibo edo laboraletan. Horretaz gain, asoziazio profesionaletako langile autonomoen kolektiboko bazkideak, komertzio ganbera eta sustatzaile gisa jarduten duten beste hainbat entitate barneratzen dira.

48 BGAELko 7. art.

49 Datu gehiagorako, kontsultatu Eusko Jaurlaritzaren Ogasun eta Finantza Departamentuaren web orrialdea: http://www.euskadi.eus/eusko-jaurlaritza/ogasun-finantza-saila/hasiera/ (azken kontsulta data 2016/04/25).

50 Datu gehiagorako, kontsultatu Gizarte Aurreikuspeneko Erakundeen Federazioaren web orria: http://www.epsv.org/home_eu.php (azken kontsulta data 25/04/2016).

51 Inbertsioen arriskuen neurketa metodologia, kontrola, sistemaren konpromisoen ezaugarrien araberako inbertsio estrategia, inbertitu dezakeen aktiboak, deribatuetan inbertitzeko aukera eta urteko errentagarritasun helburua zehaztu beharko dira.

52 92/2007 Dekretuko 5. art, maiatzaren 29koa, borondatezko gizarte aurreikuspeneko erakundeen jarduera jakin batzuk arautzen duena, EHAA n. ${ }^{\circ} 115$, ekainaren 15.

53 Esparru honetako estrategiaren deskribapena. Azalpenik ez bada ematen, ez ematearen arrazoia azalduko da. 2007/92 Dekretuaren aldaketa, maiatzaren 29koa, BGAE Araudiaren 4. Xedapenak barneratua.

54 92/2007 Dekretuko 11. art., maiatzaren 29koa. 
hainbat baldintza betetzen dituzten akzio ez kotizatuak, etab. ${ }^{55}$ Erlazio honetan 7 urte baino laburragoko epea duten kreditu entitateen ${ }^{56}$ eperako gordailuak barneratzen dira.

BGAEek KA enpresetan egiten duten inbertsioa zuzena edo zeharkakoa izan daiteke. Lehengoaren kasuan, araututako merkaturik ez duten enpresek jaulkitako akzio eta partizipazioak barneratzen dira $^{57}$. Bigarrenean, inbertsioa KAS edota $\mathrm{KAF}^{58}$ baten bitartez burututakoez.

3. taula

BGAEen inbertsioei mugak

\begin{tabular}{lcc}
\hline & $\begin{array}{c}\text { Inbertsio muga } \\
\text { (BGAEaren ondarearen } \\
\text { gain) }\end{array}$ & $\begin{array}{c}\text { Inbertsio limitea } \\
\text { (zirkulazioan dauden } \\
\text { titulu guztien emisio-balio } \\
\text { nominalaren gain) }\end{array}$ \\
\hline $\begin{array}{l}\text { Enpresa/talde baten akzio kotizatuak } \\
\text { Enpresa/talde baten akzio ez kotizatuak }\end{array}$ & $\% 5 / \% 10$ & \\
\hline $\begin{array}{l}\text { Bazkide sustatzaile edo babeslearen aktibo ez ko- } \\
\text { tizatuak }\end{array}$ & $\% 2$ \\
\hline $\begin{array}{l}\text { Higiezinetan inbertsioak eta eskubide erreal hi- } \\
\text { giezinak }\end{array}$ & $\% 20$ \\
\hline $\begin{array}{l}\text { Inbertsioa higiezin batean edo eskubide erreal } \\
\text { higiezina }\end{array}$ & $\% 10$ \\
\hline $\begin{array}{l}\text { Kapital Arriskuko Funts eta Sozietateen partizi- } \\
\text { pazio eta baloreak }\end{array}$ & $\% 20$ \\
\hline \begin{tabular}{l} 
Inbertsio Kolektiboko Instituzioak \\
\hline
\end{tabular}
\end{tabular}

Iturria: Norberak egina 92/2007 Dekretuan oinarrituta.

55 92/2007 Dekretuko 11.3 art., maiatzaren 29koa.

56 Europar Batasunean egon behar dira. Agindua, 2013ko maiatzaren 21ekoa, Ogasun eta Finantzetako sailburuarena, hainbat aktibo Borondatezko Gizarte Aurreikuspeneko Erakundeek inbertsioak egiteko aktibo egokitzat hartzeari buruzkoa, EHAA zk. 105, ekainaren 3koa.

57 92/2007 Dekretuko 11.3. m art., maiatzaren 29koa. Titulu hauek transmisio librekoak izango dira, ELGEko herrialderen batean sede soziala duen entitate batek jaulkitakoak izango dira eta euren finantza egoera auditatua izango da. Art 11.3 ń.

58 92/2007 Dekretuko 11.3.k art., maiatzaren 29koa. 22/2014 Legearen arabera, azaroaren 12koa, Kapital Arriskuko entitateak, itxitako inbertsio kolektiboko entitateak eta mota itxiko inbertsio kolektiboko entitate kudeatzaileak arautzen dituena, eta 35/2003 Legea, azaroaren 4koa moldatzen duena, Inbertsio Kolektiboko Instituzioena, BOE zk. 275, azaroaren 13 koa. 
Aipatutako BGAEen zorroen dibertsifikazio, sakabanatze eta kongruentzia inbertsio finantzario eta higiezinetakoari ${ }^{59}$ ezarritako arrisku metatze ${ }^{60}$ eta inbertsio muga batzuen bitartez sustatzen da. Hau kontutan izanik, BGAEak gutxienez \%70 errenta finko, aldakor kotizatua, IKIetako akzio eta partizipazio ${ }^{61}$, eperako gordailu, higiezinak, kreditu hipotekario eta araututako merkatuetan negoziatutako deribatuetan izan behar dute. Aurretik aipatutako goiko limitea zehazte aldera, ondorengo mugak ezartzen dira $^{62}$.

BGAEek Kapital Arriskuan egiten duten inbertsioa arriskuen metaketa eta inbertsioari ezarritako mugen bitartez arautzen da. Honela, trafiko orokorrekoak eta inpertsonalak, eta araututako merkatuetan onartuak diren baloreen kasuan, aipatutako \%70aren barne egongo lirateke. Kasu horretan, Kapital Arriskuko Entitate bakoitzean egiten den inbertsioa BGAEaren ondarearen \%5era mugatuko da, \%10era talde berdineko entitateei dagokienean. Hori gertatzen ez denean, hau da, entitatearen KA araututako merkatuetan onartua ez denean edo onartua denean baina ez denean trafiko orokorrekoa eta inpertsonala, limitea \%2koa izango da, \%4koa taldeko enpresak direnean. Horrez gain, PF batek ezin izango du KAF edo KAS batek emititutako partizipazio edo baloreen balio nominalaren $\% 20$ baino gehiago izan.

\section{Enpleguko pentsio plan eta funtsak}

1987. urtean eratu ziren, eta gaur egun 2002ko Lege ${ }^{63}$ batek (PPetaFL) eta $2004 \mathrm{ko}^{64}$ araudi batek, aurrerantzean PPetaFA, arautzen ditu. Elkarren artean loturik dauden bi zatitan banatzen da gizarte aurreikuspen osagarri instrumentu hau: Pentsio Plana eta Funtsa.

Planak erretiroa, ezgaitasuna, dependentzia eta heriotza estaltzen duten gizarte aurreikuspen kontratuak dira. Akordio boluntario, pribatu, inoiz ordezkatzen ez duten Gizarte Segurantzaren prestazioez independenteak edo osagarriak diren prestazioekin osatuak dira. Kapitalizazio sistema finantzarioa ${ }^{65}$ aplikatzen

59 GAPek Ogasun Publikoaren edo berraseguruen kontrako kredituetan eta bazkide babesleen zorretan inbertitu dezakeela kontuan hartuz.

60 92/2007 Dekretuko 11.4 art., maiatzaren 29koa.

61 Kapital Arriskukoak kanpo

62 Muga hauek ez dira aplikatuko GAPak Inbertsio Printzipioen Adierazpena izanik bere inbertsio politikak indize bat edo batzuen nahasketa errepikatzen badu.

63 Real Decreto Legislativo 1/2002, de 29 de noviembre, por el que se aprueba el texto refundido de la Ley de Regulación de los Planes y Fondos de Pensiones, BOE núm. 298, de 13 de diciembre.

64 304/2004 Dekretua, otsailaren 20koa Pentsio Plan eta Funtsen Araudia onartzen duena, BOE zk. 48, otsailaren 25ekoa.

65 «Pentsio planak kapitalizazio sistema finantzario edo aktuarialen bitartez erabiliko dira». Ikus art 2.4 PPetaFR. 
dute. Bertan, eskubide eta betebeharrak ${ }^{66}$ dituzten bakarkako eta organo ezberdinek parte hartzen dute, hala nola: sustatzailea, parte hartzailea eta onuraduna. Sustatzailea eraketan edo garapenean parte hartzen duen edozein entitate, korporazio, sozietate, enpresa, asoziazio, sindikatu edo kolektiboa da. Garrantzitsuenak parte hartzaileak dira, Planak euren interesagatik sortuak baitira. Batak eta besteak dira Planaren subjektu eratzaileak. Horiez gain, onuradunak daude, prestazioaren eskubidea aitortzen zaienak.

4. irudia

Pentsio Planaren elementu pertsonalak

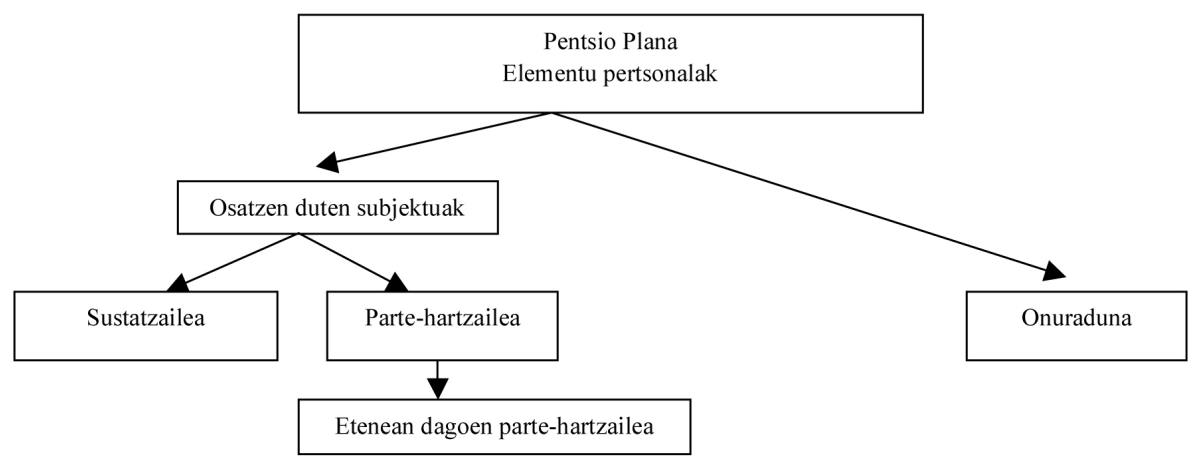

Iturria: Ahumada (2002: 55).

Enplegu planak enpresa, sozietate, korporazio edo entitate batek sortuak dira, eta bertako langileak izango dira planetako parte-hartzaileak ${ }^{67}$. Pentsio Plana Kontrol Komisioak ikuskatzen du, PPKK aurrerantzean, eta bertan sustatzailearen ordezkariak, parte hartzaileak eta onuradunak hartzen dute parte. Organo honek, gainera, aktuarioa aukeratzen du, parte hartzaileak eta onuradunak ordezkatzen ditu, eta Funtsaren Kontrol Komisioan jarduten du. PPKK ${ }^{68}$ kideak aukeratzeko edo izendatzeko prozedura bat dago, baita organo honetan erabakiak hartzeko ere ${ }^{69}$.

Pentsio-Funtsen eta Aseguruen Zuzendaritza Orokorrak ${ }^{70}$ PPetaPFei buruzko aldizkako argitalpenak egiten ditu. Iturri honen arabera, 2015eko 3. hiruhilekoaren amaierarako enplegu planek 2.072.329 parte-hartzaile zituzten

\footnotetext{
66 Ikus PPetaFLko 1. art.

67 Ikus PPetaFAko 29. art.

68 Ikus PPetaFAko 31. art.

69 Ikus PPetaFAko 32. art.

70 Datu gehiagorako ikus AAVV (2015) (azken kontsulta data 2016/04/25).
} 
eta 34.913 milioi euro. Horrek ematen du parte-hartzaile bakoitzak $16.847 €$ dituela . Prestazioei dagokienez, 1.139 milioi euro ordaindu ziren, eta 736 milioi eurotako ekarpenak egin ziren. Berriki, Asociación de Instituciones de Inversión Colectiva y Fondos de Pensiones (INVERCO) delakoak ${ }^{71} 2015$. urtearen amaieran 1.995.679 parte-hartzaileek 134.376 milioi batzen zituztela eta 80.272 onuradun zeudela argitaratu zuen. Hori kontuan hartua, 16.559 eurotako eskubide ekonomikoa da batez bestekoa parte-hartzaileak duena. Ekarpenak 1.101 milioi euro ingurukoak izan ziren, eta prestazioak 1.522 milioi eurotakoak.

PFak Planen eskubide eta betebeharrak betetzeko sortutako ondareak dira. Enplegu Plan guztiak gutxienez Funts ${ }^{72}$ batean barneratu behar dira, Enplegu Funts bat izan behar dena, Entitate Kudeatzaile eta Gordailuaren ${ }^{73}$ administrazioaren menpe egongo dena. Ondarearen kudeaketa parte hartzaileen interesen araberakoa izango da, segurtasun, errentagarritasun, dibertsifikazio, sakabanatze, likidezia, koherentzia monetario eta epea diren irizpideak euren helburuei egokituta.

Funtsaren kudeaketa Funtsaren KKak ikuskatzen du, eta bere eginkizun garrantzitsuenen artean bere inbertsio politikaren ${ }^{74}$ adierazpen ulerkorra definitzea dago, eta honi publizitate nahikoa eman behar zaio. Politika honek inbertsio erabakietan ea arrisku finantzarioez apartekoak diren arriskuak ere kontutan izan diren ala ez aipatu behar du, gai honi berariazko erreferentzia eginez ${ }^{75}$.

Funtsaren ondarea hainbat aktibotan inbertitu daiteke ${ }^{76}$ : merkatu arautuan negoziora onartutako errenta finko eta aldakorreko aktiboak, aktibo finantzario egituratuak, IKI determinatuetako akzio eta partizipazioak, kreditu entitateetako gordailuak, ondasun higiezinak eta eskubide errealak, kreditu hipotekarioak eta pignoratzaileak, deribatuak, KA eta kotizazio gabeko aktibo determinatuak, etab.

71 Inbertsio Kolektiboko Instituzio eta Pentsio-Funtsen Asoziazioa da, eta bere barne Espainiarrak diran Inbertsio Kolektiboko Instituzio gehienak daude (Inbertsio Sozietate eta Funtsak) baita Espainiar Pentsio-Funtsak, CNMVan izena emanda duten atzerriko Inbertsio Kolektiboko Instituzioak eta hainbat Partaide Kide. Ikus www.inverco.es (azken kontsulta data 2016/04/25).

72 PPen printzipioetako bat da. Ikus PPetaFAko 2.4 art. Gainera, bat baino Funts gehiagoetara egin dezake. PPetaFAko 66. art.

73 Honek kudeaketa eta gordailu komisioa sortzen du.

74 Atal honetan inbertsioen hautaketan erabilitako irizpideak ezartzen dira, arriskua neurtzeko prozedura eta bere kontrola, aktiboen banaketa estrategikoa, ikuskatzeko metodoa etab. Ikus PPetaFAko 69. art.

75 Ildo honetatik jarraituz, urteroko funtsaren kudeaketa txostenak jarraitutako inbertsio sozialki arduratsu irizpideei aipua egingo die, eta baita ezarpenerako, kudeaketarako eta jarraipenerako jarraitutako prozedurari ere.

76 PPetaFAko 70. art. 
KAren atalean, 3 bide ezberdinen bitartez hartzen da inbertsioa ontzat. Lehenengoa, 25/2005 Legeak ${ }^{77}$ araututako kapital arrisku entitateetako akzio eta partizipazioen bitartez eginiko inbertsioa. Bigarrena, ordea, merkatu erregulatuetan negoziaziora onartu gabeko errenta finkoko instrumentu eta baloreetan eginiko inbertsioa hartzen du ontzat ${ }^{78}$. Azkenik, hirugarren bat dago, merkatu erregulatuan negoziaziora onartutako instrumentu finantzario eta baloreak onartzen dituena ${ }^{79}$.

PFen zorroen dibertsifikazio, sakabanatze eta kongruentzia irizpideak inbertsio finantzario eta higiezinetako arrisku metaketari ezarritako murrizketa batzuen bitartez sustatzen dira ${ }^{80}$. BGAEtan gertatzen den bezala, PFaren ondarearen \%70a baino gehiago antolatutako merkatuetan onartutako aktibo finantzariotan, gordailu bankariotan, berme hipotekarioa duten kredituetan, higiezinetan eta higiezinen inbertsio instituzio edota inbertsio kolektiboko instituzionaletan ${ }^{81}$ inbertituko da, izaera librea dutenak salbu, antolatutako merkatuetan onartutako akzio eta partizipazioak dituztenak. Muga orokor hau ondorengo taulan zehazten da:

4. taula

PFen inbertsioei mugak ${ }^{82}$

\begin{tabular}{lcc}
\hline & $\begin{array}{c}\text { Inbertsio limiteak } \\
\text { (PFaren } \\
\text { ondarearen gain) }\end{array}$ & $\begin{array}{c}\text { Inbertsio limiteak } \\
\text { (emisiobalio } \\
\text { nominalaren gain) }\end{array}$ \\
\hline Enpresa baten trafiko orokorrean onartutako akzioak & $\% 5 / 10 / 40$ \\
\hline Talde berdineko enpresen aktibo kotizatuak & $\% 10$ \\
\hline $\begin{array}{l}\text { Aktibo ez kotizatuak edo enpresa/talde bateko trafiko ez oroko- } \\
\text { rrean kotizatuak }\end{array}$ & $\% 2 / \% 4$ \\
\hline $\begin{array}{l}\text { MAB eta MARFeko akzioak eta Kapital Arriskuko empresa/tal- } \\
\text { de-ko partizipazioak }\end{array}$ & $\% 3 / \% 6$ \\
\hline
\end{tabular}

77 22/2014 Legeak abenduaren 12koa (indargabetua) Kapital Arrisku Entitateak, mota itxiko beste inbertsio kolektiboko instituzio eta mota itxiko inbertsio kolektiboko entitateen sozietate kudeatzaileak arautzen dituena, BOE zk. 275, azaroaren 13koa.

78 Kapital Arriskuan burutzen den inbertsio honek hainbat betebehar ditu. Ikus PPetaFAko 70.9. art, a eta b atalak.

79 Kapital Arriskuan burutzen den inbertsio honek hainbat betebehar ditu. Ikus PPetaFAko 70.1. art.

80 Ikus PPetaFA 72. art.

81 85/611/CEE Direktibak eta 35/003 Legeak araututa.

82 Ez dira aplikagarriak Funtsaren Inbertsio Politika Indize bat erreplikatzea denean. 


$\begin{array}{cc}\begin{array}{c}\text { Inbertsio limiteak } \\ \text { (PFaren }\end{array} & \begin{array}{c}\text { Inbertsio limiteak } \\ \text { (emisiobalio }\end{array} \\ \text { ondarearen gain) } & \text { nominalaren gain) }\end{array}$

IKI Finantzario ${ }^{83}$ eta Gestora berdineko IKI (ez Kapital Arriskuko IKI eta IKI libreak) $\% 20$

\begin{tabular}{lc}
\hline Entitate batek emititutako tituluak & $\% 5$ \\
\hline Kapital Arrisku Funts eta Sozietateen tituluak & $\% 20$
\end{tabular}

Higiezinak, kreditu hipotekarioak, higiezinetako eskubide errealak eta IKI higiezin ez kotizatuak $\% 30$

Higiezin edo eskubide erreal baten eginiko inbertsioa, kreditu hipotekarioa, higiezinen gaineko eskubide erreala eta higiezineko IKI ez kotizatua $\% 10$

Higiezineko IKI batean eta IKI guztietan $\% 20$

Iturria: Norberak egina PPetaPFean oinarrituta.

FPak KAn inbertitzean inbertsio eta arrisku metaketa muga zehatzak dituzte. Lehenik eta behin, aipatutako \%70aren barne egongo lirateke KAko balore eta instrumentuak, negoziaziora onartutakoak. Kasu honetan, KAE bakoitzaren inbertsioa PFaren \%5era mugatzen da, eta ondoriozko \%5/10/40 erregelara. Horrela ez denean, hau da, KA antolatutako merkatuetan kotizatzera onartua ez denean edo onartua denean baina ez trafiko orokor eta inpertsonalekoak, limitea PF aren \%2koa izango da, eta \%4koan taldeko enpresatan. Burtsa Merkatu Alternatibo edo Errenta Finkokoan negoziatzera baimendua izan denen, lehenagoko mugak \%3 eta \%6koak dira, hurrenez hurren. Gainera, PF batek ezingo du KAS edo KAF batek emititutako partizipazio edo baloreen balio nominalaren \%20a baino gehiago izan.

\section{Enpleguko bgae eta enpleguko pentsio-funtsak epe luzerako inbertsio eskatzaile gisa}

BGAE eta Enplegu PFek jasotzen dituzten parte-hartzaile edo bazkideen ekarpenak inbertitzeko dira, Are gehiago, onuradunen prestazioak ordaintzeko dira etorkizunean. Helburu hori lortzen den bitartean, sortzen den diru kantitate handia aurreko puntuan aztertutako arauen arabera kudeatu behar da.

83 85/611/CEE Direktibak eta 35/2003 Legeak araututa. 
Ondare hauetan egiten den inbertsio politika definitzerako orduan, aktiboen aukeraketa eta merkatu aukerei dagokienean, denbora horizontea, dibertsifikazioa, Funtsaren Gobernu Batzordea edo KK jarrera kontutan hartzea aspektu gakoa $\mathrm{da}^{84}$.

Ondare mota hauen denbora horizontea epe luzean sailkatua izan da arrazoi ezberdinengatik, horietatik lau arrazoi nagusiak BGAE eta PPentzat komunak izanik.

Lehengo arrazoiak ondare mota hauen jatorriarekin zerikusia dauka. Enplegu sistemak nagusiki negoziazio kolektibotik datoz, eta ondorioz, pertsonala sisteman integratua egotea da ohikoena. ${ }^{85}$ Hori dela eta, sistema kolektiboa langileek eta onuradunek osatzen dute. Parte-hartzaile edo bazkideak enpresako edo enpresa taldeko langileak dira. Beste aldetik, onuradunak ohiko langileak eta hirugarren pertsonak dira. Ikuspegi honetatik, ondorioz, inbertsioen denbora horizontea kolektibotik ateratzen den adina kontutan izanik estimatu daiteke. Planak estal ditzakeen kontingentziak hainbat izan daitezke, baina erretiroa izanik ohikoena, inbertsioen denbora horizontea erretiroaren arabera ezarri daiteke, baita pixka bat gehiago ere, prestazioa errenta motakoa izan daitekeela kontutan hartuz gero.

Bigarren arrazoia bazkide/parte-hartzaileak planean duen diruaren mobilizazioarekin dauka zerikusia. Parte hartzaile/bazkidearen eskubideen mobilizazioa Planaren amaieran edo kontratu laborala baliogabetzean bakarrik da posible ${ }^{86}$, ez edozein momentutan Banako eta Elkartekide modalitateetan gertatzen den bezala. Gure herrialdean kontratu mugagabeak duen garrantzia kontutan izanik, 2015ean \%74 $\mathrm{koa}^{87}$ zena, lanbide aldaketa aukerak nahiko murritzak dira. Ondorioz, parte hartzaile eta onuradunen kolektiboaren garapena populazioaren zaharkitze naturalaren propioa izango da, Planera sartutako inkorporazio berriak eta parte hartzaileak onuradun izatera pasatzearen kasuan salbu.

Hirugarren arrazoiari dagokionez, ondarean sarrera eta irteera fluxuen zenbateko eta momentuarekin dauka zerikusia. Negoziazio kolektiboan adostutako gai bat parte-hartzaile/bazkidearen eta enpresariaren ekarpenaren zenbatekoa eta aldirokotasuna da. Gainera, aktuarioaren lana eta taula biometrikoen laguntzaz,

${ }^{84}$ Zehatzak ez diren aspektu ekonomiko-finantzarioei buruzko analisi sakonerako baterako ikus Ahumada (2001: 334-373).

85 Sistema batzuetan, lotura bezala denboraldi minimo bat eskatu daiteke: Pentsio Plan Preferenteetan, adibidez, urtebete izango da (BGAELko 14. art) eta Enplegu PPetan bi urte artekoa (PPetaFAko 5. art.).

${ }^{86}$ Kasu honetan Planaren Araudian zehaztutako kontsultatu behar da eta ea etenean dagoen bazkide/parte-hartzailearen irudia onartzen duen.

87 Datu gehiagorako ikus Populazioa Inkesta Aktiboa (EPA) 20154T, Estatistika Institutu Nazionalak argitaratua. Eskuragarri http://ine.es/daco/daco42/daco4211/epa0415.pdf (azken kontsulta data 2016/04/25). 
kontingentzia ezberdinengatik kolektiboko irteerak estimatzea posible da. Honek ondarearen kudeaketak eduki proaktiboa izan dezakeela eskatzen du, ondarearen sarrera eta irteera fluxuen zenbatekoa eta momentua estimatu daitezkeelako ${ }^{88}$.

Azkenik, eta sistema Banakoetan ez bezala, Enpleguko PP eta BGAEek, hurrenez hurren, Asanblada Orokorra eta Gobernu Batzordea eta Pentsio-Funtsen Komisio Kontrolarekin kontatzen dute. Organo hauek parte-hartzaile/bazkide, onuradun eta sustatzaileen parte-hartzearekin jarduten dute, beti ere bazkide/ parte-hartzaileen interesen alde eta era kontziente, arduratsu eta zentzuzkoan ${ }^{89}$. Hori dela eta, parte-hartzaileen eta onuradunen interesekin konprometitua dauden gobernu organoekin topo egiten dugu.

Hala ere, praktikan, arrazoi ezberdinak medio, ondarearen kudeaketa ez da hain garbi epe luzean kokatzen. Alde batetik, ondare hauen zorroen balorazio sistemak orokorki merkatu prezioan baloratzea bultzatzen $\mathrm{du}^{90}$. Honek gardentasunaren bidean pausu nabarmena eragin duen arren, askotan prezioen aldaketek epe laburreko errentagarritasunean bolatilitatea barneratzen dute, eguneroko kudeaketa eta estrategian eragina dutenak, epe luzeko erabaki estrategikoen kal$\operatorname{tetan}^{91}$.

Ondareen kudeaketa taldeen ordainsariak kudeatzaileek epe laburrerako joera izatea bultzatzen du. Ordainsari hau bi ataletan bereizten da, finkoa batetik eta aldakorra bestetik, azken hau lortutako emaitzen araberakoa izanik. Azken hau da kudeaketa epe laburrekoa izatera bultzatu dezakeena, nahiz eta emaitza hobeagokoak izan epe luzekoen kontra doana.

Gainera, INVERCO eta "Dirección General de Seguros y Fondos de Pensionessek Pentsio Planek lortutako emaitzen berri ematen dute. BGAEei dagokienean, Eusko Jaurlaritzak bere web orrialdean 2016 erdialdetik aurrera informazio hau argitaratzeko asmoa dauka. Datuak alderatzeko aukera izatea positiboa da eta gardentasunarekin lotuta dago. Hori bai, Plan ezberdinen arteko konparaketa ez da lortutako emaitzara bakarrik mugatu behar, besteak beste inbertsio politika, dibertsifikazioa, definitutako epemuga eta kudeatutako ondare bolumena ere kontutan izan behar dira. Nahiz eta azken urteetan esparru honetan aurrerapausoak egin diren eta bazkide/parte-hartzaileak sistemaren analisi bate-

88 Marko orokor honi Planen likidezia suposizioen ondoriozko diru irteerak gehitu behar zaizkio.

89 BGAELko 43. art eta PPetaFLko 14 eta 64. art.

90 Enpleguko BGAEen kasuan, ELGEko esparruan arautako merkatuetan negoziagarriak diren errenta finkoko eskubide eta baloreak «kostu amortizatu»-aren balorazio irizpidearen arabera baloratu daitezke. Informazio gehiagorako ikus AGINDUA, 2009ko apirilaren 29koa, Ogasun eta Herri Administrazioko sailburuarena. Horren bidez, BGAEen hainbat jarduera egitea arautzen duen maiatzaren 29ko 92/2007 Dekretuaren zenbait manu garatzen dira, EHAA zk. 83, 2009ko maiatzaren 6koa.

91 Aspektu honek Pentsio-Funtsen ondareen kudeaketan izan dezakeen. Ikus Ahumada (2010). 
ratua egin dezaketen, informazio horren argitaratzeak analisi zehatzago eta errealitatera egokitutakoa egitea bultzatuko luke ${ }^{92}$.

\section{Kapital arriskuaren egungo egoera bgae eta PFetan, eta etorkizuneko bilakaera: adituen iritzia}

Kapital Arriskuaren analisia BGAE eta PFetan atal honetan osatzen da, dimentsio praktikoago batekin. Hasiera batean, ondare hauetan Kapital Arriskuak duen garrantziaren analisi enpiriko bat egitea pentsatu zen. Zehatzago esanda, helburua KAk zorroetan zein neurritan irauten zuen kontrastatzea zen, baita errentagarritasun eta arriskuari dagokionean zorroari gehitzen dion balio gehigarria ere. Zoritxarrez, datu gabeziak ezinezkoa egin zuen analisi hori burutzea. BGAEen eremuan, ez dago errentagarritasun historikoa eta zorroaren banaketari erreferentzia egiten dion datu baserik ${ }^{93}$. Pentsio-Funtsei dagokienean, sektoreko iturri ofizialak, hau da, "Dirección General de Seguros y Fondos»ek, Banako eta Elkartekide modalitateko Planek lortutako errentagarritasuna ${ }^{94}$ eta kudeaketa eta gordailu komisioak ${ }^{95}$ eskaintzen ditu. Hala ere, INVERCOk ${ }^{96}$ bere web orriaren bitartez modalitate guztietako Planei buruzko informazio gehiago eta eguneratuagoa eskaintzen du. Gure esparruaren kasuan, azken 25 urteetako Planen errentagarritasunak batzen ditu. Gainera, Plana barneratzen den PFaren zorroaren banaketa ezagutu daiteke oinarrizko item batzuei esker: Inbertsio Materialak, Barneko Zorroa, Kanpoko Zorroa-errenta finko eta aldakorrean klasifikatuta, gainerako Zorroa, Beste Inbertsio batzuk, Diruzaintza, Probisio Matematikoak eta Gainerako Ondarea. Informazio honek, nahiz eta zehatzagoa izan, ez ditu Plan bakoitzak KAn egiten duen inbertsioa ezagutzen uzten, ezta errentagarritasun eta arrisku mailak ere.

Hori guztia dela eta, beste era bateko ikerketa egitea aukeratu genuen: kualitatibo erakoa. Denzin eta Lincolnen arabera (Denzin eta Lincoln, 1994:2) ikerketa kualitatibo batek errealitatea bere testuinguru naturalean ikertzen du, gertatzen den bezala, fenomenoen zentzua ateratzen edo interpretatzen, inplikatutako pertsonentzat duen esanahiaren arabera. Lan honetan BGAE eta PFek KAn egi-

\footnotetext{
92 Ranking hauek guztiz kaltegarriak dira Plan Indibidualen kasuan, kasu hauetan eskubide kontsolidatuen mobilizazioa edozein unetan posible delako.

93 2016an zehar Eusko Jaurlaritzak sistemari buruzko datu zehatzagoak argitaratzea aurreikusten du.

94 Ikus http://www.dgsfp.mineco.es/rentabilidade/Rentabilidades.aspx (azken kontsulta data 2016/04/25).

95 Ikus http://www.dgsfp.mineco.es/rentabilidade/Comisiones.aspx (azken kontsulta data 2016/04/25).

${ }_{96}$ Zehazki hilero sistemaren gain, Enplegukoak ez ezik, 3 hilabetez behin direnak. Ikus http:// www.inverco.es/38/57/0 (azken kontsulta data 2016/04/25).
} 
ten duten inbertsioaren ikuspegi, justifikazio eta aukera ondare mota hauetako kudeatzaile printzipalei eginiko elkarrizketen bitartez egiaztatu daitekeela kontsideratzen dugu. Inbertsio honen espezifikotasuna dela eta, $\mathrm{BGAE}^{97}$ eta Enpleguko $\mathrm{PF}^{98}$ printzipalekin harremanetan jartzea erabaki dugu.

BGAEn esparruan elkarrizketetan Itzarri, Elkarkidetza, Lagun Aro, Kutxabank Gestión eta Gero Pentsioakeko ${ }^{99}$ kudeatzaileek hartu zuten parte.

5. taula

Entitate parte-hartzaileak eta elkarrizketatuak (BGAE)

\begin{tabular}{ll}
\hline \multicolumn{1}{c}{ Entitatea } & \multicolumn{1}{c}{ Kudeatzailea } \\
\hline - Elkarkidetza & - Jon Aresti/Jone Alberdi \\
- Itzarri & - Unai Asenjo \\
- Kutxabank & - Joseba Orueta \\
- Lagun Aro & - Javier Urtasun \\
- Orza & - Aitor Arrizabalaga \\
\hline
\end{tabular}

Itzarri ${ }^{100}$ eta Elkarkidetza ${ }^{101}$ euskal funtzio publikoarekin lotutako kolektiboen pentsio osagarriak kudeatzea helburu duten entitateak dira. Itzarri Euskadiko Administrazio Orokor eta Instituzionaleko langileetan zentratzen da ${ }^{102}$, eta Elkarkidetza beste Instituzio, Organismo eta Euskal Sozietate Publikoe$\tan ^{103}$.

Lagun Aro ${ }^{104}$ Mondragon Korporazioko kooperatiben esparruko aurreikuspen sistema artikulatzen duen BGAE bat da. Bere helburua talde horretako

\footnotetext{
${ }^{97}$ Esparru honetan Gizarte Aurreikuspeneko Erakundeen Federazioaren parte hartzea klabea izan zen.

98 Guzti hauei gure esker onak eman nahi dizkiegu, parte hartzera izandako prestutasunagatik, eta baita hartutako adeitasunagatik ere.

99 Geroa EPSVtik ORZA, AIEri elkarrizketa egitea proposatu ziguten. ORZAren web orria http://www.orza.info/. da (azken kontsulta data 2016/04/25). Enpresa hau Elkarkidetza eta Geroa Pentsioaken partizipazioez osatua dago. Enpresa honek hazkunde proiektuak dituzten enpresen partizipazioak kudeatzen ditu. Enpresa oinordekotza eta bazkide minoritarioen ordezkapenen inguruko zalantzak ere argitzen ditu. Guzti hori epe luzeko ikuspegi batekin, eta enpresetako Administrazio Kontseiluan presentzia aktiboa izanik.

100 Itzarriren web orrialdea: https://www.itzarri.eus/ da (azken kontsulta data 2016/04/25).

101 Elkarkidetzaren web orrialdea: https://www.elkarkidetza.eus/ da (azken kontsulta data 2016/04/25).

102 Hau da Euskal Herriko Unibertsitateko eta Osakidetzako langileen kasua, esaterako.

103 Funtzionario foral eta munizipalen kasua.

104 Bere web orrialdea: https://www.lagunaro.es/ataria2/\#\&panel1-1 da (azken kontsulta data 2016/04/25).
} 
bazkide-mutualistei asistentziako eta gizarte aurreikuspeneko sistema bat eskaintzea da.

Kutxabank Gestión ${ }^{105}$ hainbat ondareren kudeaketara zuzendutako sozietatea ${ }^{106}$ da: BGAEak, PF eta IKIak. Atal honetan Enpleguko BGAE eta PFak ere barneratzen dira.

Geroa Pentsioakek ${ }^{107}$ Gipuzkoari lotutako sektore ezberdinetako enpresen lan harremanen esparruan jarduten du.

Ondorengo taulan ikusten den bezala, ikerketan parte hartu duten BGAEak lan harremanei lotutako pentsio osagarrien merkatuan adierazgarritasun nabarmena dute.

6. taula

Laginaren adierazgarritasuna enplegu sisteman

\begin{tabular}{lrrr}
\hline \multicolumn{1}{c}{ BGAE } & $\begin{array}{c}\text { Bazkideak } \\
\text { eta } \\
\text { onuradunak }\end{array}$ & $\begin{array}{c}\text { Ekarpenak } \\
(€)\end{array}$ & \multicolumn{1}{c}{$\begin{array}{c}\text { Ondarea } \\
(€)\end{array}$} \\
\hline Elkarkidetza, E.P.S.V. & 26.726 & 32.526 .232 & 965.731 .422 \\
Geroa Pentsioak, E.P.S.V. & 249.356 & 61.488 .508 & 1.622 .753 .169 \\
Itzarri, E.P.S.V. & 94.055 & 1.560 .720 & 557.695 .692 \\
Kutxabank Empleo, E.P.S.V. & 6.111 & 701.336 & 84.939 .887 \\
Lagun Aro, E.P.S.V. & 41.369 & 155.022 .000 & 5.199 .762 .000 \\
Laginaren totala & 417.617 & 251.298 .796 & 8.430 .882 .170 \\
Enplegu Sistemaren Totala & 445.078 & 271.465 .829 & 11.436 .488 .552 \\
Adierazgarritasuna & $\% 93,83$ & $\% 92,57$ & $\% 73,72$ \\
\hline
\end{tabular}

Iturria: Norberak egina Gizarte Aurreikuspeneko Erakundeen Federazioak eskainitako 2015eko bigarren hiruhilekoari dagozkion datuetan oinarrituz.

Pentsio-Funtsen esparruan, elkarrizketatuak VidaCaixa de Seguros y Reaseguros EGFP, Gestión y Previsión de Pensiones EGFP SA, Santander Pensiones EGFP SA eta Fonditel Pensiones EGFP SA izan ziren:

105 Bere web orrialdea: https://portal.kutxabank.es/cs/Satellite/portalbbk/es/kutxabank_gestion da (azken kontsulta data 2016/04/25).

$106 \% 100$ ean Kutxabankek partizipatua.

107 Bere web orrialdea: http://www.geroa.eus/Inicio.sca da (azken kontsulta data 2016/04/25). 
7. taula

Entitate parte-hartzaileak eta elkarrizketatuak (PF)

\begin{tabular}{ll}
\hline \multicolumn{1}{c}{ Entitatea } & \multicolumn{1}{c}{ Kudeatzailea } \\
\hline - BBVA & - Alberto Gómez-Reino \\
- Fonditel & - Frances Martínez \\
- Santander & - Santiago Ferrando \\
- VidaCaixa & - Ignacio García de Polavieja \\
\hline
\end{tabular}

Elkarrizketetan parte hartu duten kudeatzaile gehienak Entitate Finantzario batera loturik daude. VidaCaixa ${ }^{108}$ CaixaBanken barneratutako Entitate Kudeatzailea da. VidaCaixak entitateko PFak kudeatzen ditu, gizarte aurreikuspeneko beste produktu batzuez gain. Gestión de Previsión y Pensiones ${ }^{109}$ BBVAren Kudeatzailea da eta Santander Pensiones ${ }^{110}$ Grupo Santanderren parte da. Ez da Fonditel Pensionesen kasua ${ }^{111}$, hau Grupo Telefónicara loturik dago.

Ikerketan parte hartu duten PFek merkatuan adierazgarritasun nabarmena dute, ondorengo taulan ikus daitekeen bezala.

8. taula

Laginaren adierazgarritasuna enplegu sisteman

\begin{tabular}{lrcc}
\hline \multicolumn{1}{c}{ Kudeatzailea } & $\begin{array}{c}\text { Bazkideak } \\
\text { eta } \\
\text { onuradunak }\end{array}$ & $\begin{array}{c}\text { Ekarpenak } \\
(€)\end{array}$ & $\begin{array}{c}\text { Ondarea } \\
(€)\end{array}$ \\
\hline BBVA & 822.868 & 251.682 & 8.476 .996 \\
Fonditel & 65.369 & 133.540 & 3.464 .035 \\
Caixabank & 379.783 & 251.936 & 8.305 .607 \\
Santander & 111.185 & 91.273 & 1.271 .962 \\
Laginaren totala & 1.379 .205 & 728.431 & 21.518 .600 \\
Enplegu Sistemaren Totala & 2.075 .951 & 1.075 .676 & 34.376 .184 \\
Adierazgarritasuna & $\% 66,44$ & $\% 67,72$ & $\% 62,60$ \\
\hline
\end{tabular}

Iturria: Norberak egina INVERCOk eskainitako 2015eko abenduko datuetan oinarrituz.

108 Bere web orrialdea: https://www.vidacaixa.es/es/empresas-y-colectivos da (azken kontsulta data 2016/04/25).

109 Bere web orrialdea: https://www.bbvaassetmanagement.com/am/am/es/es/empresas/index. jsp. da (azken kontsulta data 2016/04/25).

110 Bere web orrialdea: http://www.santanderassetmanagement.es/es_ES/Santander-AssetManagement-Espana. da (azken kontsulta data 2016/04/25).

111 Bere web orrialdea: https://www.fonditel.es/Portal.aspx. da (azken kontsulta data 2016/04/25). 
BGAEen kasuan, inkesta aurrez aurre egin zen. PFen kasuan, berriz, elkarrizketak nagusiki telefonoz eginak izan ziren, bi kasutan salbu, idatzita egitea hautatu zuten eta. Inkesta 6 bloketan banatutako 10 galderaz osatua dago.

Lehengo blokean azken urteetan gizarte aurreikuspeneko instrumentuen garrantziaz galdetzen da, baita bazkide/parte-hartzaileentzat duten faktore erakargarrienez ere. Atal honetan elkarrizketatuek gizarte aurreikuspen osagarriaren gorakada aipatzen dute, pentsio publikoaren murrizketak direla eta, baita ordezkapen tasen murrizketa eta bizi itxaropen luzeago baten ondorioz ere. Horrez gain, kulturalki aurrezteko beharraren kontzientziazio handiago bat dago, aurrezkiaren fiskalitateak bultzatuta, Entitate Finantzarioek euren produktuen eskaintza indartuta eta aurreikuspen eta finantza kultura handiagoarekin batera. Hala ere, krisia, langabezia tasa altua, lan prekarietatea eta ekarpenei ezarritako mugen eraginez orain dela urte batzuetan baino maila hobea da, baina ez da nahikoa. Hainbat BGAEk esparru honetan enpresetako sindikatuen garrantzia azpimarratzen da, aurrezkiaren erregulartasuna sustatuz eta helburu bakarra aurrezki fiskala izatea ekidinez.

Elkarrizketatuen iritziz, Plan edota BGAE bat kontratatzerako orduan dauden faktore erakargarriak modalitatearen araberakoak dira. Banako Planen kasuan, adostasuna dago bi aldagai hauen inguruan: fiskalitatea eta likidezia gabezia. Fiskalitateak egun errenta erabilgarri gehiago ekartzen du etorkizunaren kontra, eta honek kontrataziora laguntzen du. Likidezia gabeziak, ordea, bere hazkuntza geldotzen du. Enplegukoen kasuan, ondorengoak ezaugarri gakoak dira; komisio baxuak, ondarearen dibertsifikazioa, epe luzeko politika estrategikoa eta negoziazio kolektiboa. Esparru honetan, fiskalitatea eta likidezia bigarren maila batean gelditzen dira. BGAE-ren batetik errenta erako erreskateetarako fiskalitate faboragarriagoa proposatzen da, eta likidezia gabeziaren garrantzia gutxiesten dute, erreskateek ondarearen \%1a bakarrik dira eta. Nahiz eta formazio finantzarioa handiagoa izan, oraindik ere asko dago egiteko, eta honek BGAE eta Planen kontratazioan eragina izango luke.

Bigarren eta hirugarren blokea BGAE eta PFen inbertsio eta araudian zentratzen dira. Ondare hauen inbertsioa tradizionalki euro errenta finkoarekin lotuta egon da (\%70-80\%), estatuko edo autonomietako zor publikoaren nagusitasunarekin, bono korporatiboez gain, ELGEko merkatuetakoak bereziki. Gainerakoa errenta aldakorrean eta diruzaintzan inbertitzen zen. Inbertsioa zuzena edo IKIen bitartez eginikoa zen. Elkarrizketatu guztiak ados daude azken urteetan zorro hauen banaketak aldaketa nabarmena jasan dutela aipatzean, zorro hauek orain dibertsifikatuagoak dira eta. Zorroa aldakorra izan da eta izaten ari da, errenta finkoa \%45-55, errenta aldakorra \%20-30, Inbertsio Alternatiboak \%5-10 eta \%2 Likidezia erako banaketa batera iritsi arte.

Alde batetik, errenta aldakorra hazi egin da, errenta finkoaren kaltetan, eta likidezia gutxiagoko instrumentuak barneratu dira, baina epe luzera itxaron- 
dako irabazi handiagoa dutenak ${ }^{112}$. Hau da aktibo higiezin eta azpiegituren kasua. Gainera, azken urteetan Inbertsio Alternatiboen garrantzia nabarmendu da, nahiz eta ez duten inoiz zorroaren pisuaren \%15a baino gehiago izan. Beste alde batetik, egungo zorroak globalagoak dira, merkatu emergenteak ${ }^{113}$ barneratuz. Gainera, kudeatutako ondareen tamainak merkatu edo aktibo batzuetan inbertsioa IKIen bitartez egitea errazten du. Horri esker erreferentziazko kudeatzaileaz gain beste kudeaketa estilo batzuk barneratzen dira, nahiz eta kudeaketa gastu «bikoitza» egin dezakeen.

Inbertsio Alternatiboetan eginiko inbertsioa —Private Equity/KA, Azpiegiturak eta Itzultze Absolutuko Funtsak, bereziki- beste herrialde batzuetan baino geldoagoa izan da. KAren kasuan, esparru honetako inbertsio esperientzia ez dela gure kulturan barneratua egon diote adituek. Horrez gain, errenta finkoaren errentagarritasunak ez zuen zorroan bestelako aktiboak barneratzerik «eskatzen». Azkenik, inbertsio horren analisiaren konplexutasuna eragozpen garrantzitsua izan zen.

Laugarren blokea BGAE eta PFek KAn egiten duten inbertsioari buruzkoa da. Kudeatzaileen ustetan inbertitzaile taldea, euren prestakuntza eta zorroen kudeaketan duten esperientzia garrantzia handikoak dira. Inbertsioa zuzena bada, BGAE eta PFek inbertitu dezaketen aktiboen erlazioaz gain, historikoki lortutako errentagarritasuna, likidezia eta gardentasuna baloratzen dute. Inbertsioa zeharkakoa den kasuetan, kudeatzailearen gaitasun kualitatibo eta kuantitatiboak ere hartzen dituzte kontutan. Positiboki baloratzen da hainbat aktiboen inbertsioan dauden mugak, KA barne, eta honek ez du egunerokoan eragozpenik ematen.

Adituen ustez, KA ez da oso gomendagarria banako sistemaren kasuan, bazkide/parte hartzaileen eskubideak egun batetik bestera mobilizatzeko aukerak ondarearen bolumenean sor dezakeen ezegonkortasunarengatik. Horrela, sistema hauetan, nahiz eta helburua epe luzekoa izan, praktikan kudeaketa epe askoz laburragokoa da.

Ez da berdina gertatzen KAk enplegu sisteman duen presentziagatik galdetzen denean, kasu hauetan denbora horizonte luzeago bat definitu daiteke eta. Kasu hauetan errenta aldakorraz gain lortu daitekeen errentagarritasun gehigarria eskaintzen duen aktibo bezala aurkezten da, horrez gain zorroa dibertsifikatuago bat eraikitzeko aukera eskaintzen duelarik. Likidezia gabeziak ondarearen errentagarritasunaren bolatilitatea gutxitzen du, gestore batek "gezurretako deskorrelazioa» deitua. Ondarean zati handi bat likidoa izan ez arren, kudeatzaile batzuek ez dute horretan arazorik ikusten. Kudeatzailearen ikuspuntutik, arazo nabarmenenak KAn inbertitzerako orduan inbertsioa altua izateko baldintza,

\footnotetext{
112 Egungo interes tipo baxuen egiturak garapen hau bultzatu du.

113 Zorroaren gainerakoekin korrelatuak ez dauden errentagarritasuna bilatu nahian.
} 
kudeatutako ondareetarako gehiegizkoak, eta merkatuan sartzeko zailtasunak dira, azken hau identifikatutako kudeatzaileen bitartez egiten delarik. Horretaz guztiaz gain, kotizatzen ez duten enpresa horien informazio falta, jarraipen, kualifikazio eta zaintza bat eskatzen dutenak, eta arriskuen kontrola eta inbertsio zuzenaren kasuan inbertitu daitekeen enpresen zerrenda "objektiboa» gehitu behar dira. Aditu batzuek KAn inbertitzeak lanpostuak sortzen dituela, teknologia bultzatzen duela, eta sistema bankariotik at egon diren enpresen hazkundea eta transformazioa bultzatzen dutela aipatzen da. Hori guztia horrela izanik, KA Inbertsio Sozialki Arduratsu (ISA) bezala aurkezten da, eta euren gertuko ingurunean sustatzen dute. Enpleguko BGAE eta PFen kasuan ISA aspektu gakoa da. Gobernu Batzorde eta Komisio Kontrolekin duten erlazioan, arrisku perfila kontserbadorea dela ikusten dute, "profesional» edukia duten karguen formazio finantzario eza eta agian KA eskatzen duen enpresaren kudeaketan ardura handiago izatea.

Bosgarren blokean herrialde anglosaxoietan izandako KAren garapena aztertzen da. Elkarrizketatuen iritziz bere aparteko garapena hainbat faktorek azaltzen dute. Gizarte Segurantzaren babes maila eskasa izanik, erretirorako aurrezkia handia eta, eta ondorioz kapitalen metatzea nabarmena da. Kapital hauek egonkorrak dira, eta honek inbertsioak epe luzeagokoak izatea bultzatzen du. Gainera, merkatu finantzarioak garatuago eta sofistikatuagoak dira, honek kapitalen mugimendua errazten duelarik. Porroterako onarpen kultura ezarrita dago bertan, eta inbertitzailearen kultura finantzarioa handiagoa da, inbertitzerako orduan selektiboagoa da eta gardentasuna eskatzen du, eta bere arrisku maila ondo neurtzen du.

Bukatzeko, KAk BGAE eta PFetan izango duen etorkizunari buruz galdetzen da. KA, Azpiegiturak, etab. egiten den inbertsioa errenta finkoaren errentagarritasun ezari lotuta dago. Gainera, hurrengo urteetarako aurreikuspena aktibo hauek errenta finkoak baino errentagarritasun altuagoa lortzea da, likideziari uko eginez eta zortzi eta hamar urte bitarteko denbora horizonte batekin. Hortaz, inbertsio honen garapen bat sumatzen da, garapen honentzat Gobernu Batzordeek eta Komisio Kontrolek jasango duten arrisku mailaren egokitzapena eta formazio finantzario handiagoa lagungarri izango direlarik.

\section{Ondorioak}

Espainiako gizarte aurreikuspen modeloa 3 pilarretan oinarritzen da. Lehenengo pilarean oinarrizko mailak, ez kontributiboa eta kontributiboa barneratzen ditu. Bigarrenean negoziazio kolektibo edo akordiotik sortutako prestazioak daude, hau da, lan harremanei lotutakoak. Hirugarrena, aldiz, aurrezkiaren eta norbanakoaren iniziatibatik sortua da. 
Azken urteetan zehar populazioaren zaharkitzea eta bizi itxaropenaren luzatzea dela eta pentsioen sistema publikoa hainbat esparrutan aldatu da. Horien artean erretirorako pentsioaren kalkulurako parametroak eta metodoei lotutakoak nabarmentzen dira, eta baita "Pentsioen errebalorizazio Indizea" eta "Jasangarritasun Faktorea» ere. Hori dela eta, ordezkapen tasak behera egin du, azken urteetako \%85-90tik aldenduz. Ondorioz, gizarte aurreikuspeneko sistema osagarriak onargarriagoak dira, enplegu motakoak bereziki.

Enpleguko BGAE eta PFek ikuspegi teoriko batetik epe luzean kokatzen diren ondareak metatzen dituzte. Aurreikuspen sistema hauen jatorria negoziazio kolektiboa izanik, egonkorrak dira eta aurretik diru sarrerak ezagutzea posible izaten da. Langile guztietara zabaldu ohi da, eta langile mugagabeek duten mobilizazio urria dela eta, ekarpen eta kontribuzioen denbora horizontea ertain luzekoa da. Lan harremana indarrean dagoen bitartean, aurrezki hori beste sistema batera mobilizatzea ezinezkoa izaten da. Azkenik, gobernu organoak sistemaren funtzionamendu egokian interesa duten pertsonek osatzen dute: bazkide/partehartzaileak, enpresaren ordezkariak eta onuradunak.

Instituzio hauek inbertitu dezaketen aktiboen erlazioa hiru iturri ezberdinen bidez ezartzen da: aktibo egokien erlazioa, inbertsioari muga eta arrisku metatzeari muga. Aktibo egokien artean KA aurkitzen da. Hazkunde edo nazioartekotze proiektuetan murgilduta dauden enpresei finantzazioa eskaintzen dien inbertsioa da, batzuetan enpresaren kudeaketa eta administrazioan parte hartzen delarik, enpresaren balioa handitzeko asmoz. Inbertsio hau bide ezberdinen bitartez gauzatu daiteke: zuzena edo zeharkakoa, hau da, KAS edo KAF bitartez. Inbertsio honen idiosinkrasiak aktiboa likidezia gabekoa edo dirutan bihurtzeko zaila izatera eramaten dute, errenta aldakorrak baino epe ertain luzeko errentagarritasun altuagoa izatera, aktibo tradizionalekin korrelazio gabe egotera, gardentasun eza eta inbertsioa baloratzeko zailtasunak izatera.

Orain urte batzuk arte Enpleguko BGAE eta PFek KAn egiten zuten inbertsioa ez da oso adierazgarria izan. Adituek hainbat arrazoi aipatzen dituzte. Alde batetik, aktibo tradizionalen errentagarritasuna — errenta finkoa eta aldakorranahikoa izan dira errentagarritasun helburua lortzeko. Hain zuzen ere interes tipo horien beherakada, errenta aldakorreko merkatuen bolatilitatea eta merkatuen globalizazioa izan dira beste aktibo batzuetan, hala nola KA, inbertitzera bultzatu dituzten faktoreak. Beste alde batetik, negozio edo enpresaren ekintzailea izatea edo enpresaren porrota onartzea ez dira gure kulturaren parte izan, merkatu ez oso garatua eta espezializatua izatera eraman duena. Gainera, Gobernu Batzordeek eta Komisio Kontrolek inbertsio tradizionalak hautatzera jotzen zuten hobeto ezagutzen zituztelako, batzuetan formazio espezializatu baten faltagatik.

Azken urteetan zehar, elkarrizketatu gehienek aurrerapausoak ikusten dituzte zentzu honetan. Hori bai, ez dira alde batera utzi behar ondare hauetan KAk garrantzi handiagoa izatea zailtzen duten aspektuak. Ikuspegi operatibo 
batetik, inbertsio bolumen baldintza minimoak daude, egun kudeatutako ondareentzat altuegiak eta merkatu garatu hauetan sartzeko zailtasunak, sarbidea erraza ez den kudeatzaile handiek kontrolatuak. Gainera, kultura eta formazioaren esparruan prozesua geldotzen duten gabeziak daudela ere kontutan izan behar da,. Hori dela eta, errenta finko eta aldakor tradizionalak ez diren inbertsioek, KA kasu, ez dute zorroaren \%15a gainditzen. KAk Etorkizunera begira, Enpleguko BGAE eta PFetan duen garrantziaz hitz egitean, kudeatzaileak baikorrak dira.

\section{Bibliografia}

\section{Liburuak eta artikuluak}

AA.VV. (1997): Libro Verde sobre los Sistemas Complementarios de Pensiones en el mercado único. Eskuragarri http://ec.europa.eu/social/main.jsp?langId=es\&catId=89\&newsId= 839\&furtherNews=yes

AA.VV. (2005): «El ciclo del capital riesgo en Europa. Su gestión y aportación de valor», Papeles de la Fundación, Ed. Fundación de Estudios Financieros, Eskuragarri http:// www.aldoolcese.es/sites/default/files/9.-118823838510.pdf

AA.VV. (2006): Plan de Previsión Social Complementaria de Euskadi, Eusko Jaurlaritza http://www.euskadi.eus/gobierno-vasco/contenidos/informacion/dd_plan_prev_ social/es_11880/adjuntos/Plan\%20Pre.\%20Soc.\%20Compl.pdf (azken kontsulta data 2016/04/25).

AA.VV. (2015): Boletín de Información Trimestral de Planes y Fondos de Pensiones 3. er Trimestre 2015. Eskuragarri http://www.dgsfp.mineco.es/planes.asp (azken kontsulta data $2016 / 04 / 25)$.

AA.VV. (2015): Encuesta de Población Activa (EPA) 20154T, http://www.ine.es/daco/ daco42/daco4211/epa0415.pdf (azken kontsulta data 2016/04/25).

AA.VV. (2013): BVCA Performance Measurement Survey 2013, http://www.bvca.co.uk/ Portals/0/library/documents/Performance\%20Measurement\%20Survey/2013\%20 Performance\%20Measurement\%20Survey.pdf

Alda García, Mercedes; Ferruz Agudo, Luis eta Compains Rivas, Javier (2009): Los sistemas de previsión social en la Unión Europea, Ed. Quiasmo, Madrid.

Alemany, Maria Luisa (2004): Impacto de las inversiones de capital riesgo en España: un análisis empírico regional (Tesis Doctoral), Universidad Complutense de Madrid, Madrid. ISBN: 84-669-2490-6.

Alemany, Maria Luisa; Álvarez, Claudia; Planellas, Marcel eta Urbano, David (2011): Libro blanco de la iniciativa emprendedora en España, ESADE Entrepreneurship Institute, Barcelona.

Álvarez Jiménez, Fernando (2005): Distressed Debt: Beneficiosy riesgos compartidos, Ed. Madrileko Burtsa. Eskuragarri http://www.bolsasymercados.es/esp/publicacion/ revista/2005/05/p53-57.pdf (azken kontsulta data 2016/04/25).

ASCRI (2012): Venture Capital \& Private Equity en España, La Asociación Española de Entidades de Capital Riesgo, Madrid.

ASCRI (2015): Informe de actividad Capital Riesgo en España, La Asociación Española de Entidades de Capital Riesgo, Madrid. 
ASCRI (2016): Resumen de la actividad de Capital Riesgo en España en 2015, La Asociación Española de Entidades de Capital Riesgo, Madrid. http://www.ascri.org/wp-content/ uploads/2015/01/Informe-ASCRI-2015.pdf (azken kontsulta data 2016/04/25).

Ahumada Carazo, Rosa María (2002): Gestión de los fondos de pensiones en los planes de pensiones de la modalidad empleo: el caso español, Tesis Doctoral. UPV/EHU, Bilbao. https://addi.ehu.es/handle/10810/2585 (azken kontsulta data 2016/04/25).

Ahumada Carazo, Rosa María (2010): «¿Afectan los criterios de valoración en la gestión estratégica de las inversiones?, XVI Jornadas del Plan de Pensiones de Empleados de Telefónica, Madrid (ejemplar multicopiado).

Ahumada Carazo, Rosa María eta Ispizua Dorna, Enea (2015): «La previsión social complementaria en el marco de las relaciones laborales: El caso Maier», Lan Harrema$n a k$, n.o 32.

Bain and Company (2015): Global Private Equity Report 2015, Bain and company, Massachusetts, http://www.bain.com/bainweb/PDFs/Bain_and_Company_Global_ Private_Equity_Report2015.pdf (azken kontsulta data 2016/04/25).

CNMV: Autorización e inscripción de FCR. Eskuragarri http://www.cnmv.es/Portal/ Legislacion/ModelosN/ModelosN.aspx?id=FCR\&idpf=4 (azken kontsulta data 2016/04/25)

Denzin, Norman K. eta Lincoln, Ivonna S. (1994): Handbook of qualitative research, London, Sage.

Errandonea Ulazia, Elixabet (2015): Sistema español de pensiones: revisión critica de los elementos comunes al cálculo de pensiones contributivas (normas sobre tope máximo de pensiones, cuantías minimas y revalorización de pensiones): Tesis Doctoral, Bilbao (ejemplar multicopiado).

Gironella Masgrau, Emilio (2005): «El apalancamiento financiero: de cómo un aumento del endeudamiento puede mejorar la rentabilidad financiera de una empresa», Revista de contabilidad y dirección, $\mathrm{n} .^{\mathrm{o}}$ 2,71-91.

Goienetxea Murgiondo, Ainhoa: (2015): El capital riesgo en la inversión de los fondos de pensiones (Trabajo Fin de Master), Facultad de Ciencias Económicas y Empresariales de la Universidad del Pais Vasco, Bilbao (ejemplar multicopiado).

Herce, Jose Antonio (2015): Las pensiones en las Comunidades Autónomas. Una lectura multidimensional de las diferencias regionales en materia de afiliación, cotizaciones y número y cuantía de las pensiones, Documento de Trabajo n. ${ }^{\circ}$ 12, Ed. Instituto BBVA de Pensiones, Madrid.

Hoyos Iruarrizaga, Jon y Blanco Mendialdua, Ana (2014): Financiación del proceso emprendedor, Pirámide, Madrid.

Kaplan, S.N. and Lerner, J. (2015): Venture Capital Data: Opportunities and Challenges. Measuring Entrepreneurial Businesses: Current Knowledge and Challenges, University of Chicago Press.

López Lubian, F., eta Hurtado Coll, R. (2008): «Los fondos de capital privado (private equity)», Estrategia Financiera, n. ${ }^{\circ}$ 255, 46-53.

Mayer, Colin; Schoorsb, Koen eta , S. eta Yafeh, Yafeh (2005): «Sources of funds and investment activities of venture capital funds: evidence from Germany, Israel, Japan and the United Kingdom», Journal of Corporate Finance, n. ${ }^{\circ} 11,586-608$ or.

OCDE (2015): Pensions at a Glance 2015 OECD and G20 Indicators, http://www.oecd. org/publications/oecd-pensions-at-a-glance-19991363.htm (azken kontsulta data 2016/04/25a). 
Van Tichelen, Arnaud (2010): El mercado secundario de los fondos de capital riesgo y su valoración (Trabajo Fin de Grado), Facultad de Ciencias Económicas y Empresariales de ICADE, Universidad Pontificia Comillas (ejemplar multicopiado).

Munnell, Alicia; Aubry, Jean-Pierre eta Crawford, Caroline (2015): Investment returns: Defined benefit vs. Defined contributions plans, Centre for Retirement Research at Boston College, abendua.

NVCA (2015): National Venture Capital Association Yearbook 2015, Thomsons Reuteurs, New York. Eskuragarri http://nvca.org/research/stats-studies/ (azken kontsulta data 2016/04/25a).

UBS (2015): A long-term perspective on pension fund investment, UBS.

\section{Araudia}

\section{Europar Batasuneko araudia}

Directiva 2009/65/CE del Consejo de 20 de diciembre de 1985 por la que se coordinan las disposiciones legales, reglamentarias y administrativas sobre determinados organismos de inversión colectiva en valores mobiliarios (OICVM) (85/611/CEE)(DO L 375 de 31.12.1. Eskuragarri http://eur-lex.europa.eu/LexUriServ/LexUriServ.do?uri $=$ CONSLEG:1985L0611:20080320:ES:PDF.

Directive 2014/50/EU of The European Parlament and of The Council on minimum requirements for enhancing worker mobility by improving the acquisition and preservation of supplementary pension rights» 2005/0214 (COD). http://eur-lex.europa. eu/LexUriServ/LexUriServ.do?uri=COM:2007:0603:FIN:EN:PDF (fecha última consulta 25/04/2016).

\section{Estatuko araudia}

Real Decreto Legislativo 1/2002, de 29 de noviembre, por el que se aprueba el texto refundido de la Ley de Regulación de los Planes y Fondos de Pensiones (BOE núm. 298, de 13 de diciembre).

LeY 35/2003, de 4 de noviembre, de Instituciones de Inversión Colectiva (BOE núm. 275, de 13 de noviembre).

LEY 27/2011, de 1 de agosto, sobre actualización, adecuación y modernización del sistema de Seguridad Social (BOE núm. 184, de 2 de agosto de 2011).

LeY 23/2013, de 23 de diciembre, reguladora del Factor de Sostenibilidad y del Índice de Revalorización del Sistema de Pensiones de la Seguridad Social (BOE núm. 309, de 26 de diciembre).

LEY 22/2014, de 12 de noviembre, por la que se regulan las entidades de capital-riesgo, otras entidades de inversión colectiva de tipo cerrado y las sociedades gestoras de entidades de inversión colectiva de tipo cerrado, y por la que se modifica la Ley 35/2003, de 4 de noviembre, de Instituciones de Inversión Colectiva.

Real Decreto 304/2004, de 20 de febrero, por el que se aprueba el Reglamento de Planes y Fondos de Pensiones, BOE núm. 48, de 25 de febrero.

Real Decreto 681/2014, de 1 de agosto, por el que se modifica el Reglamento de planes y fondos de pensiones, aprobado por Real Decreto 304/2004, de 20 de febrero. 


\section{Euskal Autonomia Erkidegoko araudia}

LeY 5/2012, de 23 de febrero, sobre Entidades de Previsión Social Voluntaria, BOPV n. ${ }^{\circ}$ 47, de 6 de marzo. Publicada también en el BOE núm. 65, del 16 de marzo.

92/2007 Dekretua, maiatzaren 29koa, borondatezko aurreikuspen sozialeko erakundeen jarduera jakin batzuk arautzeko dena.

203/2015 Dekretua, urriaren 27koa, Borondatezko Gizarte Aurreikuspeneko Erakundeen otsailaren 23ko 5/2012 Legearen Erregelamendua onartzen duena.

Agindua, 2009ko apirilaren 29koa, Ogasun eta Herri Administrazioko sailburuarena. Horren bidez, BGAE-en hainbat jarduera egitea arautzen duen maiatzaren 29ko 92/2007 Dekretuaren zenbait manu garatzen dira, EHAA n. ${ }^{\circ}$ 83, 2009ko maiatzaren 6koa.

\section{Web orrialdeak (azken kontsulta data 2016/04/25a)}

Asociación Europea de Capital Riesgo e Inversión (ASCRI): http://www.ascri.org/

BBVA Asset management: https://www.bbvaassetmanagement.com/am/am/es/es/ empresas/index.jsp

Departamento de Hacienda y Finanzas del Gobierno Vasco: http://www.ogasun. ejgv.euskadi.eus

Dirección General de Seguros y Fondos de Pensiones: http://www.dgsfp.mineco.es/

ELKARKIDETZA: https://www.elkarkidetza.eus/

Espainiako KonstituZioa https://www.boe.es/legislacion/documentos/ConstitucionEUSKERA.pdf

EVCA: http://www.evca.eu/research/activity-data/annual-activity-statistics/

Federación de Entidades de Previsión Social Vasca: http://www.epsv.org/

FONDITEL: https://www.fonditel.es/Portal.aspx

Geroa: http://www.geroa.eus/Inicio.sca

INVERCO: http://www.inverco.es/

INVEST EUROPE: http://www.investeurope.eu/

KuTXABANK: https://portal.kutxabank.es/cs/Satellite/portalbbk/es/kutxabank_gestion

LAGUN Aro: https://www.lagunaro.es/ataria2/\#\&panel1-1

National Venture Capital Association (NVCA): http://nvca.org/

ORZA: http://www.orza.info/

SANTANDER Asset Management: http://www.santanderassetmanagement.es/es_ES/

Santander-Asset-Management-Espana

SEguridad Social: http://www.seg-social.es/Internet_1/Estadistica/Est/index.htm

VIDACAIXA: https://www.vidacaixa.es/es/empresas-y-colectivos 